\title{
Carbon and nitrogen cycling on intertidal mudflats of a temperate Australian estuary. II. Nitrogen cycling
}

\author{
Perran L. M. Cook ${ }^{1,2,3,5, *}$, Andrew T. Revill ${ }^{2,3}$, Edward C. V. Butler ${ }^{2,3}$, Bradley D. Eyre ${ }^{4}$ \\ ${ }^{1}$ University of Tasmania, GPO Box 252-75, Hobart, Tasmania 7001, Australia \\ ${ }^{2}$ CSIRO Marine Research, GPO Box 1538, Hobart, Tasmania 7001, Australia \\ ${ }^{3} \mathrm{CRC}$ for Coastal Zone, Estuary and Waterway Management, Indooroopilly Sciences Centre, \\ 80 Meiers Road, Indooroopilly, Queensland 4068, Australia \\ ${ }^{4}$ Centre for Coastal Management, Southern Cross University, PO Box 157, Lismore 2480, Australia \\ ${ }^{5}$ Present address: Max Planck Institute for Marine Microbiology, Celsiusstrasse 1, 28359 Bremen, Germany
}

\begin{abstract}
Benthic fluxes of dissolved nitrogen, rates of denitrification, $\mathrm{N}_{2}$ fixation and $\mathrm{NH}_{4}{ }^{+}$ upward flux within the sediment (calculated from porewater profiles) were measured on the upper and lower mudflats at 2 study sites, 1 in the upper, river-dominated part of the estuary, and 1 in the lower, more marine part of the Huon Estuary, Tasmania, Australia. The calculated upward flux of $\mathrm{NH}_{4}{ }^{+}$from within the sediment based on porewater profiles was generally in excess of measured benthic fluxes, suggesting that $\mathrm{NH}_{4}{ }^{+}$was reassimilated at the sediment surface by microphytobenthos (MPB). The ratio of total $\mathrm{CO}_{2}\left(\mathrm{TCO}_{2}\right): \mathrm{NH}_{4}{ }^{+}$produced within the sediment was generally in excess of 15 , and in some cases in excess of 60. Significant influxes and effluxes of dissolved organic nitrogen (DON) were measured where the activity of MPB was highest. At times, DON influxes and effluxes were well in excess of dissolved inorganic nitrogen (DIN) fluxes, highlighting the importance of measuring DON fluxes where the activity of MPB is high. Rates of denitrification were very low, and represented only a small loss of $\mathrm{N}$ from the sediment, most probably as a consequence of the activity of MPB. Estimates of nitrogen assimilation by MPB showed that $\mathrm{N}_{2}$ fixation was likely to be the major source of nitrogen during the summer at the study site in the upper estuary. There was also a high estimated C:N ratio ( 20) of $\mathrm{TCO}_{2}$ and nitrogen assimilated at this site, suggesting that a significant proportion of primary production was exuded as dissolved organic carbon rather than cellular production.
\end{abstract}

KEY WORDS: Microphytobenthos · Denitrification - Intertidal - Porewater - Dissolved organic nitrogen $\cdot$ Sediment $\cdot$ Nitrogen fixation $\cdot$ Sediment-water exchange

\section{INTRODUCTION}

Because of their sheltered nature, mudflats are important zones of organic matter accumulation in coastal systems (Jickells \& Rae 1997). The remineralisation of organic matter deposited within these zones results in the release of inorganic nitrogen and phosphorus to coastal waters (Rocha et al. 1995, Falcão \& Vale 1998, Rocha 1998). In situations where a large fraction of this remineralisation proceeds via denitrifi- cation, there may be a net loss of nitrogen from the system (e.g. Dong et al. 2000). As such, mudflats may act as both sources and sinks of dissolved inorganic nitrogen. Recently, much attention has been focused on the role of intertidal sediments in attenuating high inorganic nitrogen loads from the land to the sea in temperate European estuaries (Middelburg et al. 1995b, Ogilvie et al. 1997, Trimmer et al. 1998, Cabrita \& Brotas 2000, Dong et al. 2000, Trimmer et al. 2000, Magalhães et al. 2002). 
Microphytobenthos (MPB) are ubiquitous on mudflats and may exert an important influence on nitrogen cycling processes in these environments (Underwood \& Kromkamp 1999). Assimilation of nitrogen by MPB means that effluxes of $\mathrm{NH}_{4}{ }^{+}$and $\mathrm{NO}_{3}{ }^{-}$may be drastically reduced or even reversed in the light (Sundbäck et al. 1991, Cabrita \& Brotas 2000, Magalhaes et al. 2002). In addition, MPB have been found to compete effectively with nitrifying/denitrifying bacteria for $\mathrm{NH}_{4}{ }^{+}$ and $\mathrm{NO}_{3}{ }^{-}$. Assimilation:denitrification ratios of between 2 and 10 have been reported for eutrophic mudflats, whilst ratios of between 7 and $>100$ have been reported for more oligotrophic sediments (Cabrita \& Brotas 2000, Dong et al. 2000, Sundbäck \& Miles 2000). Furthermore, MBP have also recently been shown to have a significant negative impact on denitrification, most probably via competition for nitrogen (Risgaard-Petersen 2003). These findings are significant, as they suggest that a far greater proportion of nitrogen remineralised within the sediments will be assimilated rather than denitrified, resulting in a retention of bioavailable nitrogen within the system. Recent studies have shown that sediment-dissolved organic nitrogen (DON) uptake and release may exceed that of dissolved inorganic nitrogen (DIN) in the presence of MPB, suggesting that a significant fraction of nitrogen assimilated by MPB may be returned to the water column as DON (Sundbäck et al. 2000, Eyre \& Ferguson 2002).

Where much of the MPB consists of cyanobacteria, as in cyanobacterial mats, a significant fraction of the nitrogen demand of the community may be met by $\mathrm{N}_{2}$ fixation (Stal 1995). While the importance of $\mathrm{N}_{2}$ fixation in cyanobacterial mats (Pinckney et al. 1995, Stal 1995, Paerl et al. 1996) and coral reefs (Charpy-Roubaud et al. 2001 and references therein) has received widespread attention, the importance of $\mathrm{N}_{2}$ fixation more generally by MPB, particularly in temperate areas, has received little attention. Given that cyanobacteria have been observed in temperate, highly productive MPB communities (Kristensen 1993, Sundbäck et al. 2000, Cook et al. 2004b, this volume), it seems highly likely that $\mathrm{N}_{2}$ fixation may meet a significant fraction of the nitrogen requirements of MPB. Any studies of nitrogen cycling on mudflats must, therefore, give due consideration to the central role that MPB play in the cycling of nitrogen in these environments.

To date, all studies of benthic nutrient cycling on temperate tidal flats have been conducted in European systems that have generally experienced severe eutrophication (Middelburg et al. 1995a,b, Ogilvie et al. 1997, Trimmer et al. 1998, 2000, Cabrita \& Brotas 2000, Dong et al. 2000). There is a lack of information on benthic nutrient processing in more oligotrophic estuaries (Nedwell et al. 1999). It has been proposed that prior to enrichment, European intertidal flats were net im- porters of nutrients from the sea, with tight recycling and storage of nutrients enabling these systems to support significant secondary production (Malcolm \& Sivyer 1997). In order to further investigate this hypothesis, it is necessary to obtain data from temperate oligotrophic systems. Furthermore, the currently emerging conceptual understanding of nitrogen cycling from more eutrophic European systems may not be appropriate to more oligotrophic systems such as those found in Australia (Harris 2001, Ferguson 2002). Here, the results of a study on benthic nutrient cycling in 2 intertidal mudflats in a cool-temperate, mesotrophic Australian estuary are presented. In particular, we studied the role of MPB in controlling nitrogen cycling processes including denitrification, nitrogen fixation, and dissolved organic and inorganic nitrogen fluxes.

\section{MATERIALS AND METHODS}

Sampling. Descriptions of the study sites are given in Cook et al. (2004a, this volume). Cores for the measurement of denitrification, benthic metabolism and nutrient exchange measurements were collected at Castle Forbes Bay (Site CF), a terrestrially dominated part of the estuary in March, June, September and December, and at Port Cygnet (Site PC), a marine side arm of the estuary, in April, June, September and December 2001. In spring and summer, Site PC had an approximately $50 \%$ cover of the macroalgae Gracillaria sp. During autumn and winter this was greatly reduced to $\sim 10 \%$. To facilitate comparison with other measurements, March and April are referred to as autumn; June, September, November and December are referred to as winter, early spring, late spring and summer, respectively. Nutrient fluxes were measured ex situ in the same cores and incubation set-up described in Cook et al. (2004a). While this methodology may not accurately reflect in situ exchange rates, it does allow some of the controlling factors and interactions between benthic microbial metabolism and nutrient fluxes to be evaluated (Asmus et al. 1998), which was the aim of this study. After flux experiments had finished, 1 to 2 intact sub-cores were taken from each large core for isotope-pairing measurements.

Cores ( $7 \mathrm{~cm}$ inner diameter, i.d.) for porewater analysis were taken separately, in triplicate from the upper and lower mudflats at each site, during April, August and late November 2001, and are referred to as autumn, winter and summer, respectively. An additional core was also taken at each site in April to measure porosity.

For the measurement of $\mathrm{N}_{2}$ fixation, 8 cores $(4.5 \mathrm{~cm}$ i.d. $\times 15 \mathrm{~cm}$ ) were taken haphazardly (but avoiding any areas vegetated by macroalgae) from the upper and lower mudflats at each site during February (summer), 
April (autumn), August (winter), September (spring) and October (spring) 2002. In each case, a plug of sediment approx. $6 \mathrm{~cm}$ long was taken.

Porewaters. For porewater extractions, cores were rapidly sectioned under atmospheric conditions at $0.5 \mathrm{~cm}$ intervals from 0 to $2 \mathrm{~cm}$, at $1 \mathrm{~cm}$ intervals from 2 to $4 \mathrm{~cm}$, and at $2 \mathrm{~cm}$ intervals from 4 to $8 \mathrm{~cm}$. Slices were placed in a centrifuge tube under a stream of argon (Ar) and then sealed. The sediment was centrifuged at $2000 \mathrm{rpm}$ for 10 to $15 \mathrm{~min}$. The centrifuge tubes were then placed in an Ar-purged glove box and filtered through Whatman GF/F filters. The filtrates were then frozen for later analysis of $\mathrm{NH}_{4}{ }^{+}$. Total nitrogen was also measured in the porewaters in cores taken during April and November. After $\mathrm{NH}_{4}{ }^{+}$analysis, the porewaters from each depth interval were pooled for the 3 replicate cores for the analysis of total nitrogen. Samples were stored frozen for later analysis within 3 mo for $\mathrm{NH}_{4}{ }^{+}$and within $1.5 \mathrm{yr}$ for total nitrogen. In preliminary experiments, $\mathrm{NO}_{2}{ }^{-}$and $\mathrm{NO}_{3}{ }^{-}$were not detected in the porewaters, suggesting that there were no artifacts from the oxidation of $\mathrm{NH}_{4}{ }^{+}$during core processing, and that net nitrification was not occurring within the sediment to a significant extent. Sediment porosity was determined according to Dalsgaard et al. (2000) at $1 \mathrm{~cm}$ intervals to a depth of $6 \mathrm{~cm}$.

Dissolved nutrient exchange and denitrification. Rates of nutrient exchange in the light and dark, as well as dissolved oxygen and $\mathrm{TCO}_{2}$ (data presented in Cook et al. 2004a) were measured on the $2 \mathrm{~d}$ following sampling and coincided with the period of in situ low tide. Cores were illuminated at $500 \mu \mathrm{E} \mathrm{m} \mathrm{m}^{-2} \mathrm{~s}^{-1}$ using a $50 \mathrm{~W}$ halogen lamp placed above each core. Before the commencement of flux measurements, the cores were illuminated for $\sim 1 \mathrm{~h}$, flushed with fresh site water, and capped. Rates of $\mathrm{O}_{2}, \mathrm{TCO}_{2}$ and nutrient exchange were similarly made in the dark after flushing the cores with fresh site water. We took 4 samples in a time series for nutrient and alkalinity determinations. A 'blank' core containing only water was also incubated and sampled in an identical manner to the sediment cores. Water samples taken for nutrients and alkalinity were filtered through a precombusted Whatman GF/F filter into $10 \mathrm{ml}$ screw-cap polypropylene containers. These were stored frozen for later analysis (within 3 mo for DIN, within 6 mo for total nitrogen). During the dark incubation, the dissolved oxygen (DO) was never allowed to drop below $80 \%$ of its saturated concentration. The flux across the sediment-water interface under light and dark conditions was calculated using linear regression and typically used 4 data points. The flux was only regarded as significant if the standard error was less than the magnitude of the flux.

$\mathbf{N}_{2}$ fixation. $\mathrm{N}_{2}$ fixation was determined using the acetylene reduction assay (ARA) according to Capone
(1993) as follows. The cores were returned to the laboratory within $1 \mathrm{~h}$ of collection and submerged in a water bath (40 l) of water collected from the site and incubated at in situ water temperature. Cores were stirred by a teflon-coated stirrer bar which was suspended $\sim 5 \mathrm{~cm}$ above the sediment; this was driven by an external rotating magnet rotating at 60 to $70 \mathrm{rpm}$. The following morning the water was drained from half of the cores taken from each position on the mudflat. The cores were then sealed with a clear acrylic lid (which had a rubber septum); $20 \%$ of the headspace was then replaced with acetylene that had been generated freshly from $\mathrm{CaC}_{2}$. The cores were left illuminated at $500 \mu \mathrm{E} \mathrm{m} \mathrm{m}^{-2} \mathrm{~s}^{-1}$ as described above. Ethylene was sampled from the cores 3 times during the course of the day. At dusk, the remaining cores (which had also been illuminated throughout the day in the same water bath) were incubated in exactly the same way except under dark conditions. The daytime incubations generally lasted 6 to $8 \mathrm{~h}$ and the dark incubations lasted up to $12 \mathrm{~h}$. The rate of ethylene production was calculated using linear regression of the concentration change in ethylene over time.

Experiments were also undertaken to calibrate the ratio of $\mathrm{N}_{2}$ to acetylene reduced using ${ }^{15} \mathrm{~N}-\mathrm{N}_{2}$. In February 2002, intact cores were taken from the upper mudflat at Site CF, and from the lower mudflat at Site PC. The cores were then illuminated for most of the following day. The top $0.5 \mathrm{~cm}$ of sediment was then taken from 4 or 5 cores and slurried with a small amount of site water. The slurries were then incubated in gas-tight Vacutainers (Becton Dickinson), either with acetylene or ${ }^{15} \mathrm{~N}-\mathrm{N}_{2}$ (vials pre-purged with an 80:20 He/ $\mathrm{O}_{2}$ mixture to remove unlabelled $\mathrm{N}_{2}$ in the slurry). These containers were briefly shaken for $1 \mathrm{~min}$, before being allowed to incubate in parallel at $20^{\circ} \mathrm{C}$ (the same as in situ temperature). Gas samples (50 $\mu \mathrm{l})$ were taken and analysed immediately for ethylene from the Vacutainers with added acetylene. The Vacutainers were opened in a time series corresponding to the sampling times for those samples being incubated with acetylene $(1,5,15,50 \mathrm{~h}$ intervals). Upon opening, the slurry was immediately frozen for later analysis of ${ }^{15} \mathrm{~N}$. The $\delta^{15} \mathrm{~N}$ of the sample was converted to at. $\%{ }^{15} \mathrm{~N}$ as described by Montoya et al. (1996). Linear regression analysis of the amount of excess ${ }^{15} \mathrm{~N}$ in the sediment versus time was used to calculate the rate of ${ }^{15} \mathrm{~N}$ fixation.

Denitrification. Rates of denitrification were measured using the isotope pairing technique (Nielsen 1992) described by Dalsgaard et al. (2000). After the nutrient flux experiments had been completed, subcores $(4.8 \mathrm{~cm}$ i.d. $\times 30 \mathrm{~cm})$ were taken from the original cores such that there was $\sim 8 \mathrm{~cm}$ of sediment and $17 \mathrm{~cm}$ of water column. A teflon-coated stirrer bar was then 
suspended $\sim 5 \mathrm{~cm}$ above the sediment; this was driven by an external rotating magnet rotating at 60 to $70 \mathrm{rpm}$. Light and dark incubations were performed with 4 cores from each site on the following day. Dark cores were double-wrapped in aluminium foil; light was provided as described previously (third subsection of 'Materials and methods'). Experiments commenced with the addition of stock ${ }^{15} \mathrm{NO}_{3}{ }^{-}$to a final concentration of $60 \mu \mathrm{M}$. This concentration was chosen after a concentration series experiment (as described by Rysgaard et al. 1995) had shown that concentrations of ${ }^{15} \mathrm{NO}_{3}{ }^{-}$above $20 \mu \mathrm{M}$ gave constant values of denitrification. Samples were taken for analysis of $\mathrm{NO}_{3}{ }^{-}$before and after the addition of ${ }^{15} \mathrm{NO}_{3}{ }^{-}$in order to calculate final ${ }^{15} \mathrm{~N}$ enrichment. Cores were then capped and left for $2 \mathrm{~h}$ to allow the added ${ }^{15} \mathrm{NO}_{3}{ }^{-}$to diffuse into the denitrification zone and attain equilibrium. Cores were sacrificed over a time span that allowed the DO to decrease by no more than $20 \%$ below saturation. They were sacrificed as follows: $1 \mathrm{ml}$ of $50 \% \mathrm{ZnCl}_{2}$ was added to the water overlying the sediment, and the sediment was gently slurried with the water column using a metal rod; coarser particles were allowed to settle for about $1 \mathrm{~min}$ before a $40 \mathrm{ml}$ sample was taken using a gas-tight syringe. The sample was then placed in a $12 \mathrm{ml}$ Exetainer (Labco) to which $250 \mu \mathrm{l}$ of $50 \% \mathrm{w} / \mathrm{v} \mathrm{ZnCl}_{2}$ had been added. A headspace of $\mathrm{He}$ was introduced into the Exetainer within $2 \mathrm{wk}$, and the samples were subseqently analysed within several months. Denitrification rates were calculated according to the isotope pairing equations of Dalsgaard et al. (2000).

Sample analysis. $\mathrm{NH}_{4}{ }^{+}$was analysed using $o$-phthalaldialdehyde (OPA) derivatisation and fluorescence detection ( $\mathrm{R}$. Watson et al. unpubl. data); the precision of the method was generally between 5 and $8 \%$ with a detection limit of 0.07 to $0.2 \mu \mathrm{M}$. $\mathrm{NO}_{2}{ }^{-}$and $\mathrm{NO}_{3}{ }^{-}$were determined on a Technicon Autoanalyser using sulphanilamide derivatisation of $\mathrm{NO}_{2}^{-} ; \mathrm{NO}_{3}^{-}$was determined as $\mathrm{NO}_{2}^{-}$after cadmium reduction to $\mathrm{NO}_{2}^{-}$(modified from Grasshoff 1976). The limit of detection of the analysis was $0.05 \mu \mathrm{M}$ for $\mathrm{NO}_{2}{ }^{-}$and $0.1 \mu \mathrm{M}$ for $\mathrm{NO}_{3}{ }^{-}$; the precision for both analyses was typically less than $3 \%$. Total dissolved nitrogen was determined as $\mathrm{NO}_{3}{ }^{-}$ after persulphate digestion modified from Valderrama (1981); the precision was generally $<5 \%$ and the limit of detection was $5 \mu \mathrm{M}$. Dissolved organic nitrogen (DON) was calculated as the difference between total nitrogen and DIN $\left(\mathrm{NO}_{2}^{-}+\mathrm{NO}_{3}{ }^{-}+\mathrm{NH}_{4}{ }^{+}\right)$; the precision for this analysis was $10 \%$. Total dissolved primary amines (TDPA) were analysed according to the method of Petty et al. (1982); the precision of the method was $1.5 \%$ and the limit of detection was $<0.1 \mu \mathrm{M}$. Urea was analysed on a Technicon Autoanalyser according to the method of Price \& Harrison
(1987); the limit of detection was $0.25 \mu \mathrm{M}$ and the precision was $<5 \%$.

Ethylene of sampling was determined within $1 \mathrm{~d}$ using a Hewlett Packard 5890 gas chromatograph equipped with an Alltech AT Alumina column (30 m, $0.53 \mathrm{~mm}$ i.d.) and a flame ionisation detector. The ${ }^{15} \mathrm{~N}$ enrichment of sediment samples were analysed using a Carlo Erba NA1500 CNS analyser interfaced via a Conflo II to a Finnigan Mat Delta $\mathrm{S}$ isotope-ratio mass spectrometer. Analysis of ${ }^{28} \mathrm{~N}_{2},{ }^{29} \mathrm{~N}_{2}$ and ${ }^{30} \mathrm{~N}_{2}$ was carried out using this same mass spectrometer interfaced to a Hewlett Packard 5890 GC.

Modelled sediment $\mathrm{NH}_{4}{ }^{+}$production rates. Estimates of the upward flux of $\mathrm{NH}_{4}{ }^{+}$within the sediments were made using Fick's first law:

$$
F=-\varphi\left(D_{\mathrm{s}}+D_{\mathrm{e}}\right) \frac{\Delta C}{\Delta x}
$$

where $\varphi$ is porosity, $\Delta C / \Delta x$ is the concentration gradient obtained using linear regression of the linear portion of the concentration profiles ( 4 to 5 data points), $D_{\mathrm{e}}$ is the enhanced sediment diffusion of solutes and $D_{\mathrm{s}}$ is the sediment diffusivity. $D_{\mathrm{s}}$ was calculated according to Iversen \& Jørgensen (1993). An estimate of enhanced diffusion $\left(D_{\mathrm{e}}\right)$ was obtained by comparing the measured fluxes of oxygen to those calculated from $\mathrm{O}_{2}$ micro-profiles. Micro-profiles were taken during August 2001 at all sample sites using OX 25 (25 $\mu \mathrm{m}$ tip diameter) $\mathrm{O}_{2}$ micro-electrodes (Unisense, Aarhus, Denmark). The calculated $\mathrm{O}_{2}$ consumption rates were then compared to those measured in intact cores taken in June (Site $\mathrm{CF}$ ) and September (Site PC). It was assumed that sediment respiration rates were the same in the cores taken for the flux and micro-profile measurements. $D_{\mathrm{e}}$ was calculated according to Berg et al. (2001):

$$
D_{\mathrm{e}}=D_{\mathrm{s}}\left(\frac{F_{\text {meas }}}{F_{\text {calc }}}-1\right)
$$

where $F_{\text {meas }}$ is the measured flux in intact cores and $F_{\text {calc }}$ is the calculated diffusive flux profile assuming $D_{\mathrm{e}}=0$. Diffusion coefficients for $\mathrm{NH}_{4}{ }^{+}$were obtained from and corrected for temperature according to $\mathrm{Li}$ \& Gregory (1974). Diffusion coefficients for $\mathrm{O}_{2}$ were obtained from Broeker \& Peng (1974).

Nitrogen assimilation by microphytobenthos. The rates of nitrogen uptake by MPB were estimated using the dissolved nitrogen benthic fluxes and the calculated upward fluxes of $\mathrm{NH}_{4}{ }^{+}$within the sediment derived from this study. If there was a flux of $\mathrm{NH}_{4}{ }^{+}$into the sediment during illumination, then the assimilation by MPB of $\mathrm{NH}_{4}{ }^{+}$produced within the sediment was calculated as $A_{\mathrm{NH}_{4}}=J_{\mathrm{NH}_{4}}-J_{\mathrm{D}} \times \mathrm{D}$, where $A_{\mathrm{NH}_{4}}=$ daily assimilation of $\mathrm{NH}_{4}{ }^{+}$by benthic microalgae; $J_{\mathrm{NH}_{4}}=$ daily upward flux of $\mathrm{NH}_{4}{ }^{+}$from within the sediment; $J_{\mathrm{D}}=$ dark efflux of $\mathrm{NH}_{4}{ }^{+} ; \mathrm{D}=$ daily dark period. 
If an efflux of $\mathrm{NH}_{4}{ }^{+}$was measured from the sediment during illumination, it was assumed that $\mathrm{NH}_{4}{ }^{+}$met the nitrogen demand in excess of that measured for the uptake of dissolved nitrogen from the water column (see below). Under such conditions it was assumed that algal cells assimilated nitrogen in a C: $\mathrm{N}$ ratio of 6.6.

For the spring budget calculation, the winter production rates of $\mathrm{NH}_{4}{ }^{+}$within the sediment were used, as porewater profiles were not taken in spring. This seems reasonable given that the winter and spring temperatures were not greatly different and the calculated rates of $\mathrm{NH}_{4}{ }^{+}$production within the sediment did not vary greatly over the course of the year. We assumed that all the upward flux of $\mathrm{NH}_{4}{ }^{+}$was assimilated by MPB even when there was apparently a zone of consumption within the sediment. We believe this is reasonable given that the purpose of this budget was to estimate the maximum possible uptake of $\mathrm{NH}_{4}{ }^{+}$by MPB.

The assimilation of water-column nitrogen species was calculated as follows $A_{\mathrm{N}}=J_{\mathrm{L}} \times \mathrm{L}+J_{\mathrm{D}} \times \mathrm{D}$, where $A_{\mathrm{N}}=$ assimilation of an individual nitrogen species; $J_{\mathrm{L}}=$ light uptake of nitrogen species; $J_{\mathrm{D}}=$ dark uptake of nitrogen species; L and D = light and dark periods, respectively.

The standard error due to spatial variability in the calculated $\mathrm{NH}_{4}{ }^{+}$upward fluxes, the light and dark fluxes of dissolved nitrogen species, as well as an estimated uncertainty of $1 \mathrm{~h}$ in the lengths of the light and dark periods were propagated through the calculation. The whole $\mathrm{NO}_{3}{ }^{-}$flux into the sediment was assumed to be assimilated by MPB, because the rates of denitrification were relatively low. Assimilation of $\mathrm{NO}_{3}{ }^{-}$produced within the sediment was assumed to be insignificant, as in preliminary studies no $\mathrm{NO}_{3}{ }^{-}$was detected in the surface porewaters. No correction was made for tidal exposure, since we wanted to obtain a maximum estimate of the rates of dissolved nitrogen uptake by MPB in the core set-up. The daily photoperiod used was the same as that used by Cook et al. (2004a).

Statistical analysis. The statistical analysis used Statistica Version 6.0 (StatSoft). A 1-way and a 2-way analysis of variance (ANOVA) were carried out on logtransformed data. Where log-transformation failed to correct heteroscadisticity (as indicated by a Cochran's $C$-test, a non-parametric test was used. Correlation and multiple regression analysis were used to explore relations between variables.

\section{RESULTS}

\section{Denitrification}

Denitrification rates $\left(D_{14}\right)$ at Site $C F$ were not significantly affected by time or position on the mudflat (2-way ANOVA). Denitrification was undetectable during light incubations on the upper mudflat for all seasons; rates in the dark ranged from $0.3 \mu \mathrm{mol} \mathrm{m}^{-2} \mathrm{~h}^{-1}$ in autumn to $3 \mu \mathrm{mol} \mathrm{m} \mathrm{m}^{-2} \mathrm{~h}^{-1}$ in summer (Fig. 1). On the lower mudflat, denitrification was detected in both the light and dark; rates varied between undetectable in spring and $2.3 \mu \mathrm{mol} \mathrm{m} \mathrm{m}^{-2} \mathrm{~h}^{-1}$ in autumn. A large difference between light and dark denitrification rates was seen in autumn on the lower mudflat, when benthic productivity was highest.

Denitrification at Site PC was significantly greater on the lower than the upper mudflat (2-way ANOVA, $\mathrm{p}<0.01)$. A significant interaction between position and time showed that this varied significantly with time; however, the interaction was much smaller than for the effect of position, indicating that time had a relatively small influence.

Denitrification was not related to temperature in either the light or the dark (data pooled from both sites). Light and dark denitrification had positive relationships with light and dark $\mathrm{NH}_{4}{ }^{+}$fluxes; the relationship was strongest under light conditions $(r=0.77$, $\mathrm{p}<0.01$ ) (data pooled from both sites), indicating that availability of $\mathrm{NH}_{4}{ }^{+}$played a role in controlling rates of denitrification. Photosynthesis by MPB apparently had a negative effect on denitrification in the light, as indicated by the significant correlations with $\mathrm{TCO}_{2}$ $(\mathrm{r}=0.50, \mathrm{p}<0.05)$ and $\mathrm{O}_{2}$ fluxes $(\mathrm{r}=-0.53, \mathrm{p}<0.05)$ (data pooled from both sites).

\section{Dissolved inorganic nitrogen fluxes}

Light and dark conditions had a marked influence on the benthic fluxes of $\mathrm{NO}_{2}^{-}, \mathrm{NO}_{3}^{-}$and $\mathrm{NH}_{4}^{+}$(DIN) (Fig. 1). Under light conditions, DIN was either taken up at a greater rate or released at a lower rate compared to dark conditions. During the course of the year, none of the DIN fluxes differed significantly between the upper and the lower sites of either mudflat (Kruskal-Wallis, p > 0.05), with the exception of dark $\mathrm{NO}_{3}{ }^{-}$fluxes at Site PC. At this site, $\mathrm{NO}_{3}{ }^{-}$uptake by the sediment was more rapid on the upper mudflat (Kruskal-Wallis, $\mathrm{p}<0.01$ ). All the data from the upper and lower mudflats were then pooled for each site and the 2 sites were compared on an annual basis. Release of $\mathrm{NH}_{4}{ }^{+}$from the sediment was significantly greater on average at Site PC than at Site CF (Kruskal-Wallis, p < 0.01). The sediments at Site CF were always a sink for $\mathrm{NH}_{4}{ }^{+}$in the light, and also (more generally) during the dark. Flux rates ranged from an uptake $\left(-28 \mu \mathrm{mol} \mathrm{m}^{-2}\right.$ $\mathrm{h}^{-1}$ ) on the upper mudflat in the light to an efflux (39 $\mu \mathrm{mol} \mathrm{m} \mathrm{m}^{-2} \mathrm{~h}^{-1}$ ) in the dark during summer. At Site $\mathrm{PC}, \mathrm{NH}_{4}{ }^{+}$was generally released from the sediments under both light and dark conditions, with the highest 


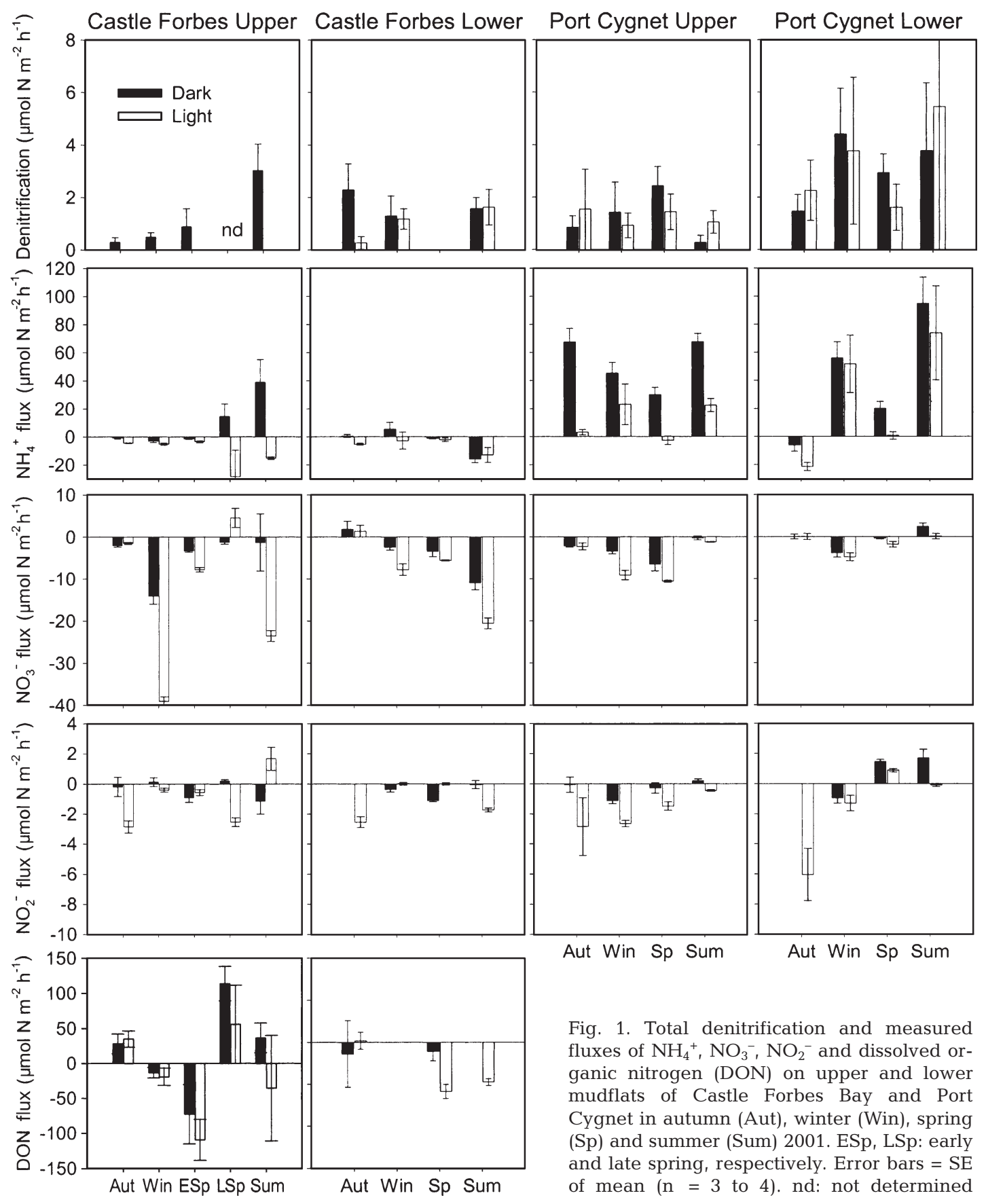

efflux of $\mathrm{NH}_{4}{ }^{+}$occurring during summer $\left(95 \mu \mathrm{mol} \mathrm{m}{ }^{-2}\right.$ $\mathrm{h}^{-1}$ ). $\mathrm{NO}_{3}{ }^{-}$was taken up at a significantly greater rate in both the light and dark at Site CF than at Site PC (Kruskal-Wallis, $\mathrm{p}<0.05$ ). $\mathrm{NO}_{3}^{-}$fluxes into the sediment were significantly correlated to $\mathrm{NO}_{3}{ }^{-}$concentrations in the water column under both light and dark conditions when the data from both sites were pooled $(\mathrm{r}=0.60, \mathrm{p}<0.05)$. Fluxes of $\mathrm{NO}_{3}{ }^{-}$and $\mathrm{NO}_{2}{ }^{-}$were not significantly correlated, with $\mathrm{NO}_{2}^{-}$making up between 0 and $90 \%$ of NOx fluxes.

\section{Dissolved organic nitrogen fluxes}

No significant fluxes of DON were detected at Site PC. Significant DON fluxes were always detected at Site CF on the upper mudflat and occasionally on the lower mudflat (Fig. 1). Fluxes of DON were not measured on the lower mudflat in winter, and were assumed to be insignificant. Treatment (light/dark) was not found to have a statistically significant effect on DON fluxes (Kruskal-Wallis, p > 0.05); however, 

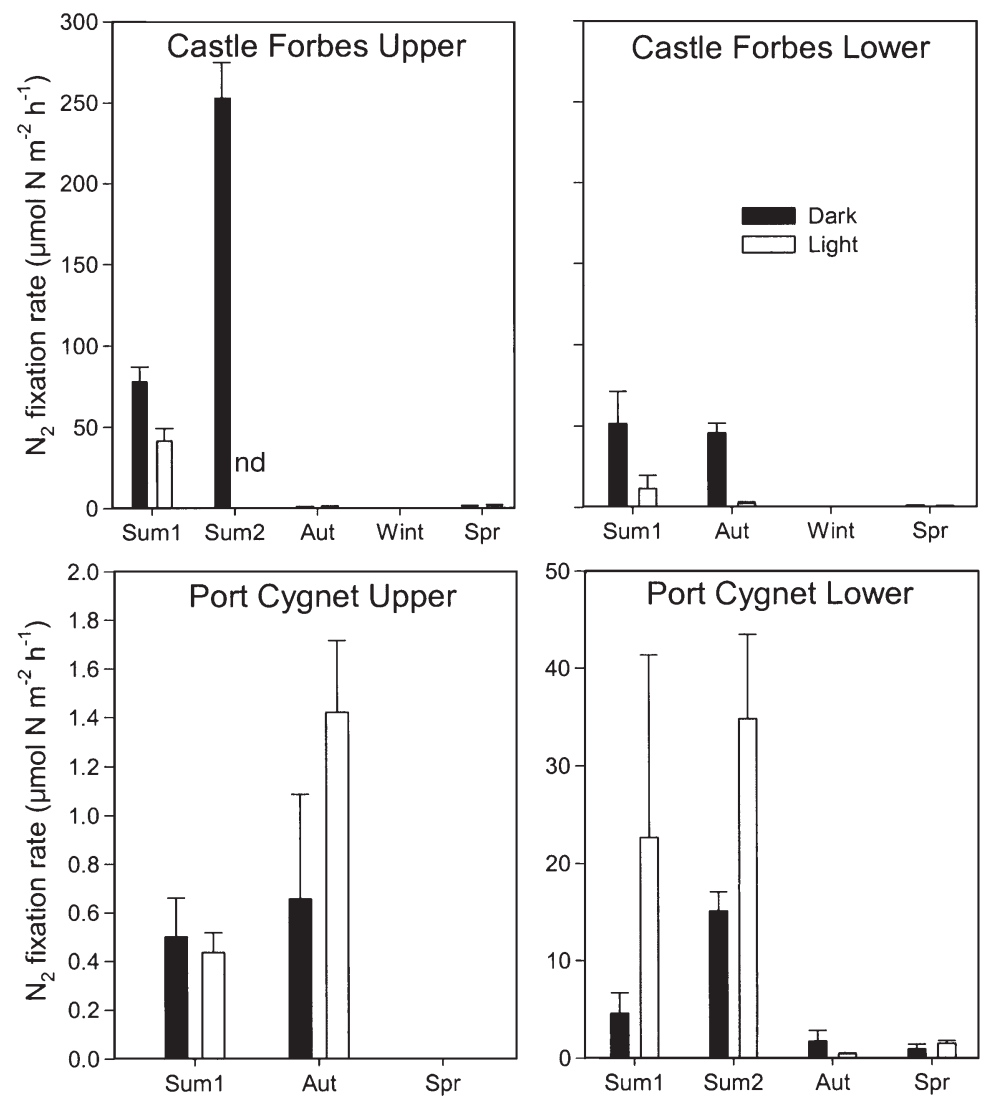

Fig. 2. Rates of nitrogen fixation measured by acetylene reduction assay under light and dark conditions at each of study sites in summer (Sum), autumn (Aut), winter (Win) and spring (Spr) 2002. Sum 1, Sum 2: samples taken on 3 and 13 February on upper mudflat at Site CF and on 6 and 10 February on lower mudflat at Site PC, respectively. Rates of nitrogen fixation calculated using acetyleneto- $\mathrm{N}_{2}$ ratio of 4 (see 'Materials and methods' for details). nd = not determined. Error bars $=\mathrm{SE}$ of mean $(\mathrm{n}=3$ to 4$)$

there was generally a greater release (or lower uptake) of DON in the dark compared to the light. Highest DON effluxes were observed on the upper mudflat in late spring $\left(113 \mu \mathrm{mol} \mathrm{m}{ }^{-2} \mathrm{~h}^{-1}\right)$, coinciding with highest respiration rates (Cook et al. $1994 \mathrm{a}$, and present Fig. 1). Highest uptake rates were observed in early spring $\left(-109 \mu \mathrm{mol} \mathrm{m} \mathrm{m}^{-2} \mathrm{~h}^{-1}\right)$, coinciding with highest productivity. In this study, we measured both urea and total dissolved primary amines (TDPA). Even when the highest effluxes of DON occurred during November, urea and TDPA fluxes were insignificant $(<5 \%$ of total fluxes).

\section{$\mathbf{N}_{2}$ fixation}

The average ratio between acetylene reduced and

${ }^{15} \mathrm{~N}$ fixed was $5.0 \pm 0.7$ at Site $\mathrm{CF}$ and $7 \pm 2$ at Site PC. The acetylene: $\mathrm{N}_{2}$ ratios determined here were within 2 of their respective standard errors of the theoretical acetylene: $\mathrm{N}_{2}$ ratio. It was therefore assumed that the measured ratio was not significantly different from the theoretical ratio of $4: 1$.

Rates of $\mathrm{N}_{2}$ fixation measured by the ARA were highly variable, ranging from undetectable to $250 \mu \mathrm{mol} \mathrm{m}{ }^{-2} \mathrm{~h}^{-1}$ (Fig. 2). The highest rates of $\mathrm{N}_{2}$ fixation were observed on the upper mudflat at Site CF during summer. $\mathrm{N}_{2}$ fixation rates were generally highest in the dark at Site CF upper and CF lower. At Site PC, in contrast, the rates of $\mathrm{N}_{2}$ fixation tended to be greater in the light. Dark rates of $\mathrm{N}_{2}$ fixation were significantly greater at Site CF than at Site PC on an annual basis (KolmogorovSmirnov test, $\mathrm{p}<0.025)$. There was no significant difference in the light $\mathrm{N}_{2}$ fixation rates between Sites PC and CF on an annual basis.

\section{$\mathrm{NH}_{4}{ }^{+}$porewater profiles and calculated upward fluxes}

$\mathrm{NH}_{4}{ }^{+}$concentrations at all sites generally increased down the profiles, reflecting the production of $\mathrm{NH}_{4}{ }^{+}$within the sediments (Fig. 3). At both study sites, the porewater concentrations of $\mathrm{NH}_{4}{ }^{+}$were highest on the upper mudflat. $\mathrm{NH}_{4}{ }^{+}$ concentrations were lowest during winter at all sites, and generally similar during autumn and late spring. Concentrations within the porewaters were approximately $1 \mu \mathrm{M}$ in the upper $3 \mathrm{~cm}$ of sediment on the upper mudflat and in the upper $6 \mathrm{~cm}$ on the lower mudflat. Calculated rates of $\mathrm{NH}_{4}{ }^{+}$production were generally highest on the upper mudflat at PC and lowest on the lower mudflat at Site CF.

Profiles of DON were generally highly variable, showing no consistent trend with depth (data not shown). Where a depth concentration gradient was apparent, it was generally less than the gradient for $\mathrm{NH}_{4}{ }^{+}$. Blackburn \& Blackburn (1993) suggested a diffusion coefficient of $5.8 \times 10^{-6} \mathrm{~cm}^{2} \mathrm{~s}^{-1}$ for DON, which is approximately a third of that used for $\mathrm{NH}_{4}{ }^{+}$. This means that for DON to be produced at rates comparable to $\mathrm{NH}_{4}{ }^{+}$, it would have to have a concentration gradient 3 times greater than that for $\mathrm{NH}_{4}{ }^{+}$, which was not the case here. Therefore, rates of DON production within these sediments were considered to be negligible compared to $\mathrm{NH}_{4}{ }^{+}$production rates, and are not considered further.

\section{Nitrogen assimilation by MPB}

Estimated rates of nitrogen assimilation ranged from $280 \mu \mathrm{mol} \mathrm{m}{ }^{-2} \mathrm{~d}^{-1}$ for the lower mudflat at Site CF dur- 
ing autumn to $3460 \mu \mathrm{mol} \mathrm{m} \mathrm{m}^{-2} \mathrm{~d}^{-1}$ at the upper mudflat at Site PC during summer (Table 1). Calculated assimilation rates of dissolved fixed nitrogen in 2001 were generally higher than the assimilation of $\mathrm{N}_{2}$ gas via nitrogen fixation measured during 2002, with the exception of summer for both mudflats at Site CF and autumn for the lower mudflat at Site CF. During summer for Site $\mathrm{CF}$, the measured $\mathrm{N}_{2}$ fixation rates (average of 2 sampling dates: Fig. 2) for the upper mudflat were higher than the calculated assimilation of total dissolved nitrogen at any other time of the year at this site. This suggests that $\mathrm{N}_{2}$ fixation will be an important source of nitrogen to the MPB community at Site CF during the summer months when dissolved nitrogen concentrations are low and there is high light availability.

The assimilation ratio of $\mathrm{TCO}_{2}$ and total dissolved nitrogen at Site CF was generally very high (11 to 164) during 2001. When the maximum rates of $\mathrm{N}_{2}$ fixation measured at each site were included in the estimated

Table 1. Estimated rates of daily total dissolved nitrogen assimilation by microphytobenthos in 2001, measured rates of nitrogen fixation in 2002, and estimated assimilation ratios of $\mathrm{TCO}_{2}$ and nitrogen at Castle Forbes Bay (CF) and Port Cygnet (PC) during course of each year. Values in parentheses: estimated error in values derived from propagation of uncertainties in spatial variability ( $\mathrm{n}=3$ to 4 cores). C:N ratios: Max. = estimated from daily rates of production and the estimated total dissolved $\mathrm{N}$ assimilation in 2001; Avg. = ratio estimated from daily production rates and estimated total dissolved $\mathrm{N}$ assimilation in 2001 plus annual average rate of $\mathrm{N}$ fixation measured at that site in 2002; Min. = ratio estimated from daily production rates and estimated total dissolved $\mathrm{N}$ assimilation plus maximum rate of $\mathrm{N}$ fixation measured at that site in 2002. ${ }^{*}$ Efflux of $\mathrm{NH}_{4}{ }^{+}$from sediment during illumination; it was therefore assumed that cells showed growth at Redfield ratio $(6.6)$; nd: no data

\begin{tabular}{|cccccc|}
\hline \multirow{2}{*}{ Season } & $\begin{array}{c}\text { N assimilation rate, } \\
2001\end{array}$ & $\begin{array}{c}\mathrm{N}_{2} \text { fixation rate, } \\
2002 \\
\left(\mathrm{mmol} \mathrm{N} \mathrm{m}^{-2} \mathrm{~d}^{-1}\right)\end{array}$ & \multicolumn{3}{c}{ C:N ratio } \\
$\left(\mathrm{mmol} \mathrm{N} \mathrm{m}^{-2} \mathrm{~d}^{-1}\right)$ & & & & \\
\hline CF upper & & & & & \\
Autumn & $809(33)$ & 25 & $92(14)$ & 49 & 18 \\
Winter & $1625(214)$ & 0 & $16(3)$ & 11 & 6.6 \\
Spring & $2907(731)$ & 31 & $43(12)$ & 34 & 20 \\
Summer & $894(703)$ & 3342 & $97(77)$ & 53 & 20 \\
CF lower & & & & & \\
Autumn & $281(668)$ & 784 & $164(390)$ & 90 & 38 \\
Winter & $405(172)$ & 0 & $11(5)$ & 6.9 & 6.6 \\
Spring & $1199(226)$ & 13 & $31(7)$ & 26 & 17 \\
Summer & $1305(105)$ & 915 & $39(6)$ & 34 & 23 \\
PC upper & & & & & \\
Autumn & $1591^{*}$ & 20 & 6.6 & - & - \\
Winter & $1206^{*}$ & nd & 6.6 & - & - \\
Spring & $1173(266)$ & 0 & $30(7)$ & 29 & 29 \\
Summer & $3461^{*}$ & 11 & 6.6 & - & - \\
PC lower & & & & & \\
Autumn & $843(38)$ & 32 & $76(19)$ & 67 & 52 \\
Winter & $791^{*}$ & nd & 6.6 & - & - \\
Spring & $2418^{*}$ & 25 & 6.6 & - & - \\
Summer & $1594^{*}$ & 387 & 6.6 & - & - \\
\hline
\end{tabular}

ratio of $\mathrm{TCO}_{2}$ to nitrogen assimilated, this ratio thoped to that expected for balanced growth during vere generaly effuxes of 17 to 38 . At Site PC there the light, assumed to be balanced with the exception of 2 periods of high productivity, for which the estimated ratio of C:N assimilated was 29 (PC upper mudflat in spring) and 52 (PC lower mudflat in autumn) when the maximum rate of $\mathrm{N}_{2}$ fixation measured at these positions

At Site CF, DON made up a significant fraction of the nitrogen assimilated, particularly in the lower mudflat, where DON generally dominated nitrogen uptake by the sediment during autumn and spring (Fig. 4). As a consequence of the low rates of $\mathrm{NH}_{4}{ }^{+}$production in the sedite $\mathrm{NH}_{4}{ }^{+}$produced within the sediments only appeared to be of minor importance to MPB mudflat at Site $\mathrm{CF}_{\text {; }}$ in the upper mudflat, $\mathrm{NH}_{4}{ }^{+}$produced within the sediment made up a variable fraction of the nitrogen assimilated. During autumn over $90 \%$ of nitrogen assimilated was from $\mathrm{NH}_{4}{ }^{+}$produced within the sediment, and during spring $<30 \%$ of nitrogen assimilated originated from within the sediment. $\mathrm{NH}_{4}{ }^{+}$ produced within the sediments was the most important source of nitrogen to MPB at Site PC year-round. No significant fluxes of DON were observed at Site PC. DIN from the water column generally comprised only a very small fraction of the measured nitrogen uptake by MPB, except during winter, when concentrations of $\mathrm{NO}_{3}^{-}$and $\mathrm{NO}_{2}^{-}$were elevated in the water column.

\section{DISCUSSION}

\section{Estimated upward fluxes of $\mathrm{NH}_{4}{ }^{+}$ within sediments}

The exchange of solutes across the sediment-water interface due to molecular diffusion is generally 2 to 4 times lower than the observed bulk fluxes in nearshore sediments due to activity of fauna within the sediment (e.g. Archer \& Devol 1992, Berg et al. 2001, Green et al. 2004). The enhanced transport of solutes across the sediment-water interface in cohesive sediments in these and previous studies is attributable to either the pump- 
(a) Castle Forbes Bay
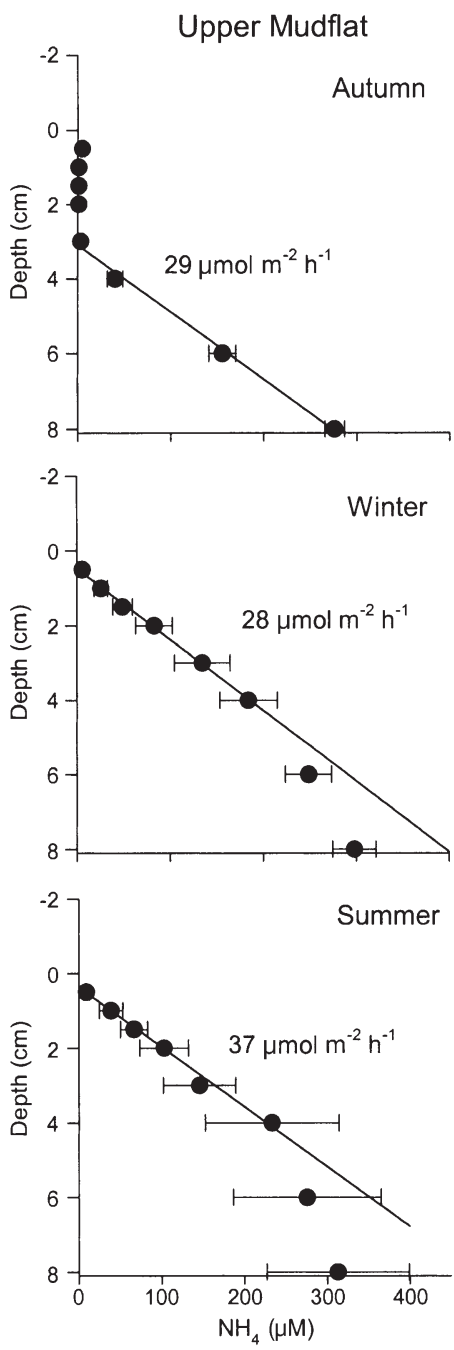

Lower Mudflat
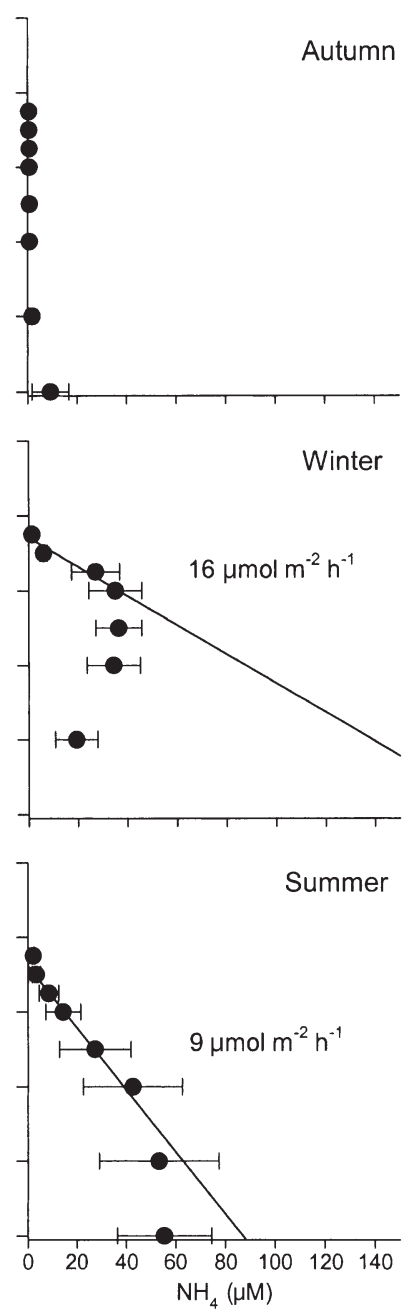

(b) Port Cygnet

Upper Mudflat
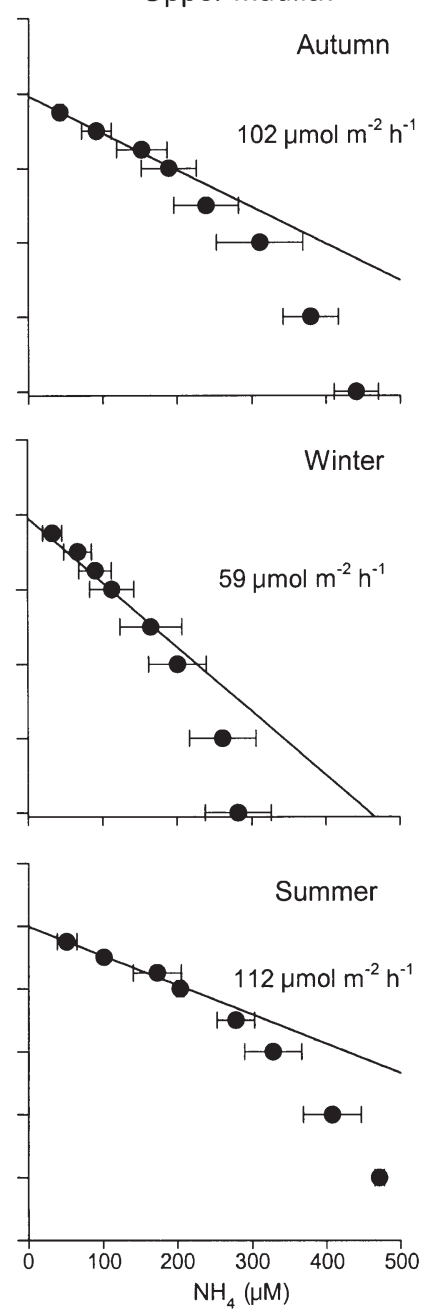

Lower Mudflat

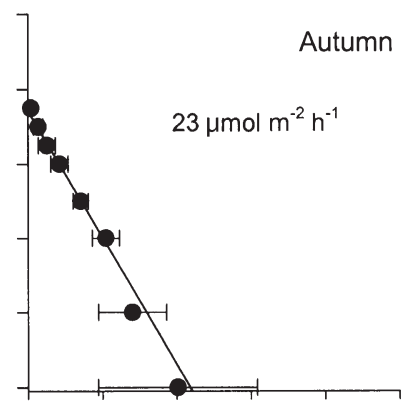

Winter

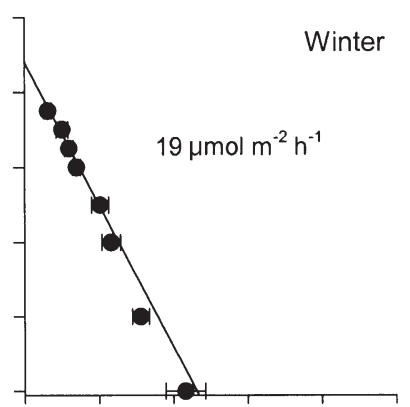

Summer

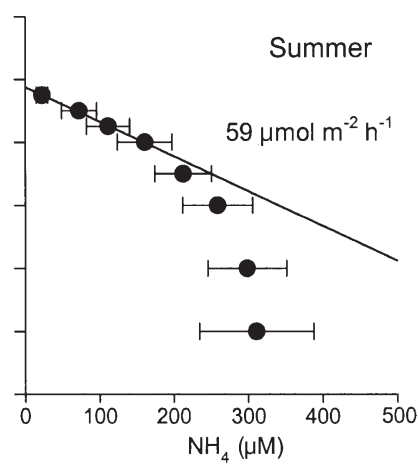

Fig. 3. Porewater profiles of $\mathrm{NH}_{4}^{+}(\bullet)$ and regression lines used to calculate upward fluxes of $\mathrm{NH}_{4}{ }^{+}$via diffusion and enhanced diffusion (see 'Materials and methods' for details) at (a) Castle Forbes Bay and (b) Port Cygnet in autumn, winter and summer. Error bars $=\mathrm{SE}$ of mean $(\mathrm{n}=3)$
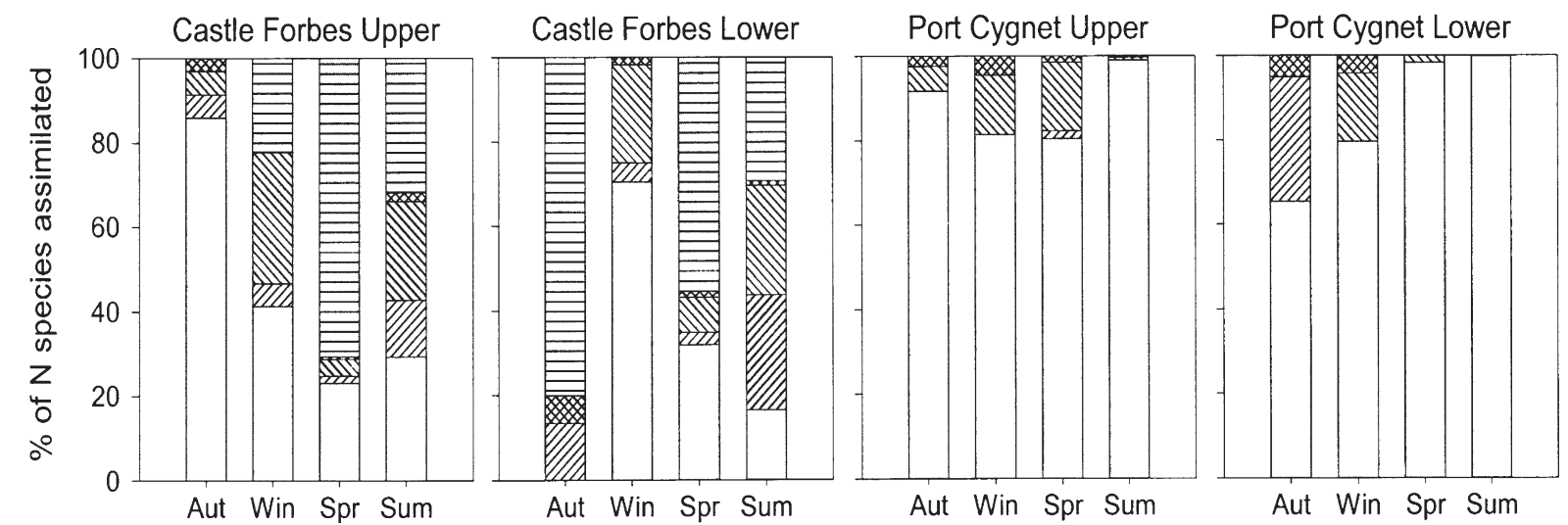

$\Longleftarrow \mathrm{PW} \mathrm{NH}_{4}$ एسm $\mathrm{WCNH}_{4}$ $\mathrm{WC} \mathrm{NO}_{3}^{-}$ $\mathrm{WC} \mathrm{NO}_{2}^{-}$ $\rightleftharpoons$ WCDON

Fig. 4. Proportions of various forms of nitrogen assimilated from water column (WC) and porewater (PW) by microphytobenthos at each study site during course of the year 
ing activity of fauna (bio-irrigation) or the random movements of fauna within the sediment (enhanced diffusion). Enhanced diffusion can be simply modelled using Fickian diffusive models, whereby an enhanced diffusion coefficient $\left(D_{\mathrm{e}}\right)$ is calculated, as done by Berg et al. (2001) and Meile \& Van Cappellen (2003). Bio-irrigation is more complicated to model, and should theoretically be modelled using a nonlocal exchange model (Meysman et al. 2003). Nevertheless, the biodiffusive model has often been successfully applied in an empirical manner to nearshore, oceanic and mesocosm sediments (Soetaert et al. 1996, Matisoff \& Wang 1998, Meile \& Van Cappellen 2003, Green et al. 2004). This apparent contradiction between theory and practice has been termed the 'biodiffusion paradox' (Meysman et al. 2003). In the present study we used the enhanced diffusion model to estimate the upward fluxes of $\mathrm{NH}_{4}{ }^{+}$, as described in 'Materials and methods'. We believe this to be justified in this case for several reasons: (1) The sediments were initially checked for fauna and very few polychaetes and pumping bivalves were observed ( 4 small, $<2 \mathrm{~cm}$ long individuals per core, equivalent to $\sim 250$ individuals $\mathrm{m}^{-2}$ ). Berg et al. (2001) estimated the relative effect of similar fauna densities on a bioturbation coefficient as $4.6 \times 10^{-6}\left(\frac{1}{2}\right.$ to $1 / 8$ of those estimated here) for oxygen, and found that bio-irrigation would only account for $\sim 11 \%$ of the estimated oxygen uptake. Given that we measured higher values of $D_{\mathrm{e}}$ one would expect the effect of fauna on our fluxes to be relatively smaller and thus insignificant. (2) With a few exceptions, the profiles we obtained presented little evidence of bio-irrigation, with the profiles showing an outward curvature. Under the influence of bioirrigation one would expect to see a more sigmoid profile shape for $\mathrm{NH}_{4}{ }^{+}$(Mortimer et al. 1999, Tuominen et al. 1999). Some of the profiles did show a sigmoid shape at the surface, suggesting either consumption of $\mathrm{NH}_{4}^{+}$within the sediment or non-local exchange. We did not quantify macrofauna during these experiments, but inspection of the cores after the experiments were complete, and during core slicing suggested that the cores were relatively devoid of macrofauna $\left(\$ 300 \mathrm{~m}^{-2}\right)$ and burrows. (3) There was generally no significant difference between the oxygen fluxes measured in the exposed and inundated sediments of these cores (Cook et al. 2004a). If bio-irrigation was a significant process, then one would expect to see much higher exchange rates of $\mathrm{O}_{2}$ in the sediment during inundation because the pumping activity of fauna would cease upon sediment exposure.

The values of $D_{\mathrm{e}}$ obtained using this approach were $10.2 \times 10^{-6}$ for both mudflats at Site $\mathrm{CF}$, and 38 $\times 10^{-6}$ for the upper and $18 \times 10^{-6}$ for the lower mud- flat at Site PC. A $D_{\mathrm{e}}$ of $11.9 \times 10^{-6}$ was reported at a shallow station in Disko Bay in Greenland by Rysgaard et al. (2000) (referred to as $D_{B}$ in that paper). Berg et al. (2001) cited $D_{\mathrm{e}}$ values in the order of $10^{-6}$ to $10^{-4}$. The $D_{\mathrm{e}}$ values measured here are, therefore, within the range of values expected in bioturbated sediments.

An indication of the accuracy of the upward $\mathrm{NH}_{4}{ }^{+}$ flux calculated from porewater profiles is perhaps best obtained by comparing the measured fluxes to the calculated production rates during periods of low productivity by MPB when assimilation of $\mathrm{NH}_{4}{ }^{+}$at the surface is likely to be negligible. The lowest rates of primary production were observed for the lower mudflat at Site CF during summer, when there was also only a small difference between light and dark fluxes, indicating that the assimilation of $\mathrm{NH}_{4}^{+}$by MPB was negligible. At this time, the calculated production rate of $\mathrm{NH}_{4}{ }^{+}$within the sediment was $74 \pm$ $28 \mu \mathrm{mol} \mathrm{m} \mathrm{m}^{-2} \mathrm{~h}^{-1}$ compared to a measured flux of $94 \pm$ $18 \mu \mathrm{mol} \mathrm{m} \mathrm{m}^{-2} \mathrm{~h}^{-1}$. The overlapping standard errors of both these estimates suggest that they are not significantly different, indicating that the calculated upward fluxes of $\mathrm{NH}_{4}{ }^{+}$within the sediment are close to the true values.

In general, the calculated upward fluxes of $\mathrm{NH}_{4}{ }^{+}$ were greater than those actually measured in the dark (Fig. 5a). In many instances, particularly at Site CF, there was an uptake of $\mathrm{NH}_{4}{ }^{+}$from the water column, which suggests that $\mathrm{NH}_{4}{ }^{+}$was being consumed at the sediment surface. Nitrification and subsequent denitrification are unlikely to be the $\mathrm{NH}_{4}{ }^{+}$-consuming process, because $\mathrm{NO}_{3}{ }^{-}$was not detected in these porewaters and rates of denitrification were extremely low. Assimilation by MPB is the most likely explanation, given the high MPB biomass and productivity at these sites, combined with the low water-column concentrations of DIN. This seems plausible, as MPB are able to assimilate $\mathrm{NH}_{4}{ }^{+}$and $\mathrm{NO}_{3}{ }^{-}$for up to $60 \mathrm{~h}$ in darkness (Rysgaard et al. 1993). It is unclear whether MPB were responsible for the $\mathrm{NH}_{4}{ }^{+}$consumption below the sediment surface, which in some instances extended to a depth of $3 \mathrm{~cm}$ (Fig. 3a). Other studies have suggested that MPB are capable of consuming nutrients in the surface-sediment layers, in some instances down to depths of $3 \mathrm{~cm}$ (Sundbäck et al. 1991, Thornton et al. 1999). The MPB observed at this site were dominated by Oscillatoria spp. (Cook et al. 2004b) which are highly motile and were observed to move several centimetres up and down the side of the core tubes. It is therefore plausible that the MPB are capable of assimilating $\mathrm{NH}_{4}{ }^{+}$from depths of several centimetres down into the sediment. It is also possible that sediment bacteria are responsible for the uptake of $\mathrm{NH}_{4}{ }^{+}$observed in these sediments, as discussed below. 

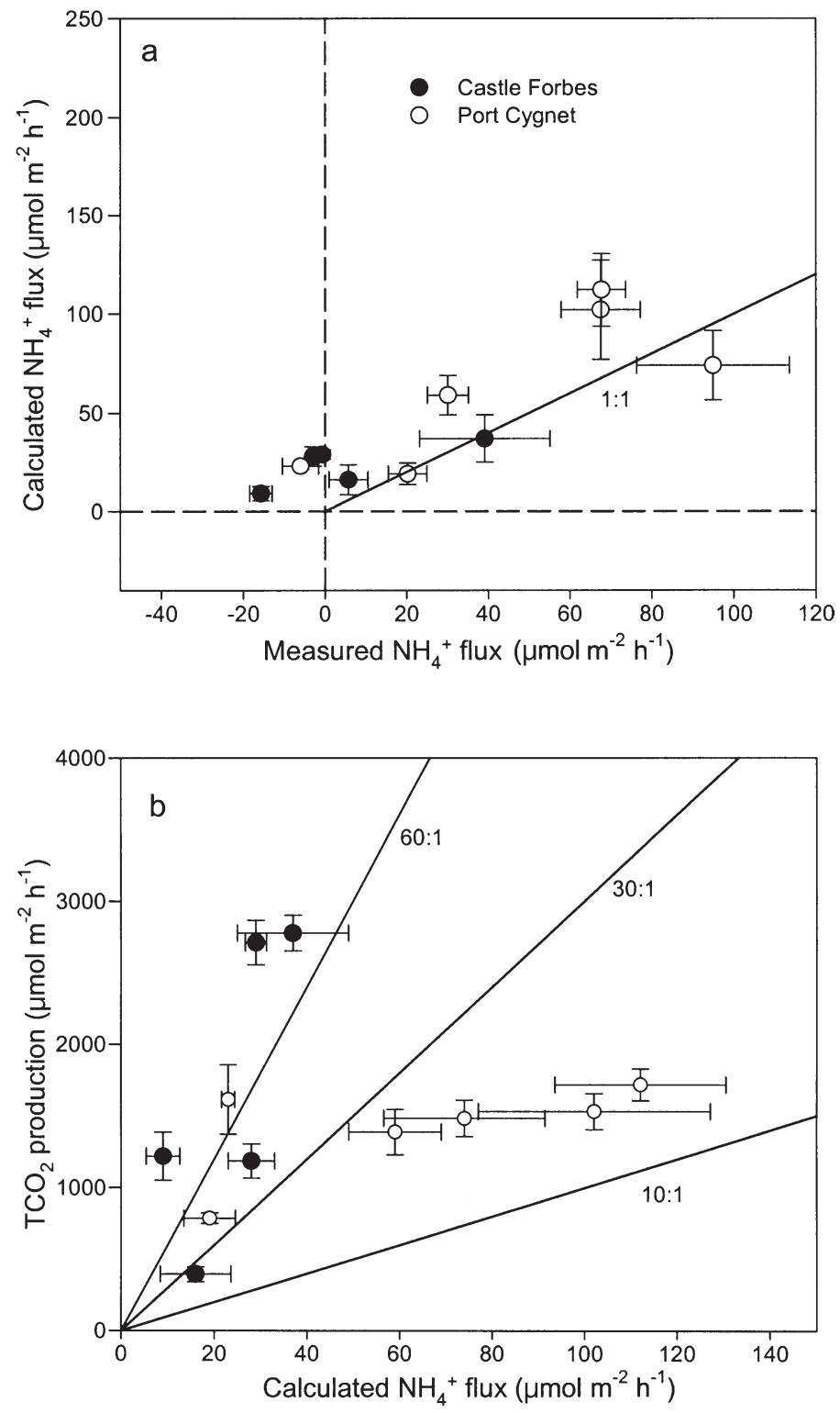

Fig. 5. (a) Calculated upward flux of $\mathrm{NH}_{4}{ }^{+}$within sediment versus measured dark $\mathrm{NH}_{4}{ }^{+}$flux at Castle Forbes Bay and Port Cygnet; line shows 1:1 relationship between modelled and measured fluxes. (b) Dark total $\mathrm{CO}_{2}$ flux versus calculated upward flux of $\mathrm{NH}_{4}{ }^{+}$within sediment at Castle Forbes Bay and Port Cygnet; lines show $\mathrm{TCO}_{2}: \mathrm{NH}_{4}{ }^{+}$ratios of 10,30 and 60 . Error bars $=\mathrm{SE}$ of mean $(\mathrm{n}=3$ to 4$)$

The ratio of the calculated upward flux of $\mathrm{NH}_{4}{ }^{+}$to $\mathrm{TCO}_{2}$ produced in the sediment generally fell within the range of 1:10 to 1:60 (Fig. 5b). This would suggest that the organic material undergoing decomposition either had a very high $\mathrm{C}: \mathrm{N}$ ratio and/or that nitrogen reassimililation was occurring in the porewaters. It is suggested (see below) that a fraction of the carbon fixed by MPB in these sediments is directed to the pro- duction of extracellular organic carbon (EOC) as a consequence of overflow metabolism. The importance of EOC as a labile carbon source to benthic consumer animals and bacteria is now recognised (Decho 1990, Goto et al. 2001). This material is generally considered to consist predominantly of simple sugars and polysaccharides (Decho 1990, Underwood et al. 1995). The nitrogen content of EOC has been poorly investigated; however, it has been suggested that the importance of EOC as a nitrogen source to consumers is minimal (Decho 1990). A recent study has shown that amino acids comprised up to $5 \%$ of EOC (Granum et al. 2002). If it is assumed that all the nitrogen in EOC is present as amino acids with an average $\mathrm{C}: \mathrm{N}$ ratio of 2 , then a $\mathrm{C}: \mathrm{N}$ ratio of $\sim 40$ for EOC is conceivable. EOC, therefore, may represent a labile, high $\mathrm{C}: \mathrm{N}$ ratio source of organic carbon to bacteria and meiofauna within the sediment.

In one instance, the $\mathrm{C}: \mathrm{N}$ ratio for the net production of $\mathrm{TCO}_{2}$ and $\mathrm{NH}_{4}^{+}$was 110, and in another instance approached infinity. Whether or not the $\mathrm{C}: \mathrm{N}$ ratio of the remineralised carbon and nitrogen reflects the $C: N$ ratio of the organic matter undergoing remineralisation will depend on whether or not the population of bacterial cells remineralising the organic matter are in steady-state. A pulsed input of labile organic matter to sediments has been shown to stimulate bacterial production, resulting in an uptake of inorganic nitrogen by bacteria in order to synthesise their low C:N ratio biomass (van Duyl et al. 1993, Pedersen et al. 1999). Bacterial production may also be continuously stimulated by a ready supply of labile organic carbon derived from MPB, as well as grazing within the sediment (Meyer-Reil \& Faubel 1980, Kemp 1990, Epstein 1997, Coull 1999). Thus, a continuous uptake of nitrogen and transfer into the microbial food web may take place (Blackburn 1988). As such, it is suggested the generally high ratio of $\mathrm{TCO}_{2}: \mathrm{NH}_{4}{ }^{+}$production was caused by the decomposition of labile high $\mathrm{C}: \mathrm{N}$-ratio EOC, which stimulated the reassimilation of $\mathrm{NH}_{4}{ }^{+}$by actively growing bacteria. The consequence of this is that only a very small net release of nitrogen into the porewaters relative to carbon oxidised was observed.

A lack of nutrient production within the porewaters of mangrove sediments is also commonly observed, and is ascribed to a reassimilation of nutrients by bacteria, which ultimately sequester the nutrients within the sediments (Alongi et al. 1992). Similar findings have been made in subtropical systems in northern New South Wales, where it was also found that estuarine sediments generally acted as a sink for nutrients (Ferguson 2002). This suggests that in more oligotrophic systems there will be a rapid incorporation of DIN into biomass and a tight cycling of nitrogen within the biotic nitrogen pools. 


\section{Dissolved organic nitrogen fluxes}

The most significant DON fluxes were measured for the upper mudflat at Site CF, where the highest MPB biomass, productivity and respiration rates have been observed (Cook et al. 2004a). This is consistent with previous studies which have shown that DON effluxes may be significant where there are high inputs of fresh organic matter (Hansen \& Blackburn 1992, Enoksson 1993, Blackburn et al. 1996, Pedersen et al. 1999, Tyler et al. 2001), including that derived from MPB (Eyre \& Ferguson 2002, Ferguson 2002). The most significant DON effluxes were observed when sediment respiration rates were highest during late spring 2000. It is suggested that this high respiration rate reflected the breakdown of MPB from an early spring bloom, as observed in the following spring of 2001 (Cook et al. 2004a). During this period, the efflux of DON dominated over DIN fluxes. The low DIN effluxes observed at Site CF throughout the year support previous observations that DON will be the major dissolved species of nitrogen to be released to the water column from sediments with high organic matter inputs from MPB and macroalgae (Tyler et al. 2001, Eyre \& Ferguson 2002). A possible mechanism for this is an uptake of DIN by MPB and subsequent release of DON by algal cells (Nagao \& Miyazaki 2002). Grazing of MPB and subsequent release of DON to the water column through 'sloppy feeding' has also been suggested as mechanism of DON release from sediments (Eyre \& Ferguson 2002). Alternatively, low C:N-ratio DON may be lost in the early stages of decomposition of algal material, leaving behind a relatively high $\mathrm{C}: \mathrm{N}$-ratio carbon pool (Blackburn et al. 1996). Bacteria degrading this pool then assimilate inorganic nitrogen to synthesise their own biomass, resulting in a low efflux of inorganic N. Whatever the exact mechanism of DON production, it most probably occurs right at the sediment surface, since porewater DON profiles did not suggest any significant accumulation (and hence production, given its low diffusion coefficient) within the sediment (data not shown).

Of particular interest in terms of its bioavailability is the identity of the DON lost from the sediment, especially during the period of high efflux during late spring. Herein, we measured urea and TDPAs and found the fluxes of these species to be insignificant. Other studies that investigated the composition of DON produced within the sediment also found that urea was a minor component of the DON pool (Blackburn et al. 1996, Lomstein et al. 1998, Pedersen et al. 1999). Dissolved free amino acids (DFAA) have generally been found to make up $<10 \%$ of the DON pool and fluxes in sediments (Lomstein et al. 1998, Pedersen et al. 1999, Landén \& Hall 2000). The TDPA method used here will only determine primary amino acids and will, therefore, only determine a sub-fraction of the DFAA pool. The low efflux of TDPAs seen here is consistent with DFAA measurements in other systems. Total hydrolysable amino acids (THAAs) have been identified as a significant proportion of DON pools and fluxes within sediments, making up $26 \%$ of DON in shallow-water sediments (Lomstein et al. 1998). Pedersen et al. (1999) found that THAAs constituted $17 \%$ of DON flux in the first $7 \mathrm{~d}$ following eelgrass addition to sediments. The bulk fraction of DON released from sediments remains to be identified. In general it has been observed that DON released from the sediments will have a low $\mathrm{C}: \mathrm{N}$ ratio $(\$ 6)$, suggesting that $\mathrm{DON}$ released from sediments is not refractory (Blackburn et al. 1996, Burdige \& Zheng 1998, Pedersen et al. 1999). It has been suggested that a large fraction of DON efflux may be composed of compounds such as RNA and amines (Lomstein et al. 1998, Pedersen et al. 1999).

\section{Denitrification}

Measuring denitrification in intertidal sediments only during inundation imposes a degree of artificiality on the rates of denitrification measured. Sediment exposure may lead to changes at the sediment surface, potentially affecting the activity of nitrifying and denitrifying bacteria. In particular, the lack of a supply of $\mathrm{NO}_{3}{ }^{-}$from the water column during exposure will mean that coupled denitrification will be the only denitrification pathway. A recent study has suggested that rates of coupled denitrification are unchanged during exposure (Ottosen et al. 2001). Rates of denitrification were generally low, but comparable to those measured using the isotope pairing technique on other intertidal flats during times of low water column $\mathrm{NO}_{3}{ }^{-}$ concentrations (Cabrita \& Brotas 2000, Trimmer et al. 2000). Similarly, low rates have also been observed in shallow subtidal coastal sediments (Rysgaard et al. 1995, Jensen et al. 1996, Sundbäck et al. 2000). A number of reasons for the low rates of denitrification are possible. Low concentrations of $\mathrm{NO}_{3}{ }^{-}$in the water column would have resulted in greatly reduced rates of diffusion of $\mathrm{NO}_{3}{ }^{-}$into the sediment, which would mean that uncoupled rates of denitrification were also relatively low. Denitrification rates may also be depressed in the intertidal zone because of its more extreme and fluctuating environmental conditions (Ottosen et al. 2001).

Benthic microalgal production also had a negative impact on denitrification, as indicated by the negative correlations between various productivity indicators and denitrification. Fig. 6 shows that denitrification was always much less than the $\mathrm{NO}_{3}{ }^{-}$influx into the 
sediment, suggesting that assimilation of $\mathrm{NO}_{3}{ }^{-}$from the water column by MPB detracted from uncoupled denitrification. Potential negative effects of primary production on coupled denitrification include competition for $\mathrm{NH}_{4}{ }^{+}$and $\mathrm{CO}_{2}$ between photoautotrophs and nitrifying bacteria, and possible increases in $\mathrm{pH}$ and $\mathrm{O}_{2}$ (Henriksen \& Kemp 1988, Risgaard-Pedersen et al. 1994). Competition for $\mathrm{NH}_{4}{ }^{+}$between nitrifiers and heterotrophic bacteria will also have a negative impact upon nitrification rates (Strauss \& Lamberti 2000), and possibly also denitrification (Risgaard-Petersen 2003). The stimulation of heterotrophic bacterial activity by MPB (see earlier in 'Discussion') is therefore another means by which the presence of MPB will negatively impact coupled denitrification.

At Site PC, denitrification rates were always significantly higher on the lower mudflat than on the upper mudflat. This is in agreement with the findings of Ottosen et al. (2001), who found rates of denitrification at an intertidal site to be 3 times lower than at a nearby subtidal site. Rates of primary production were not significantly different between the upper and lower mudflat (Cook et al. 2004a), suggesting that a factor other than primary production was important in controlling the rates of denitrification in this system. As suggested by Ottosen et al. (2001), the most likely reason for the higher rates of denitrification in the subtidal zone is that this is a more stable environment, sheltered from the great changes in temperature and salinity that an exposed mudflat experiences. The lower mudflat sediment in this study also had a much higher porosity and oxygen penetration (data not shown), which could allow greater rates of coupled denitrification.

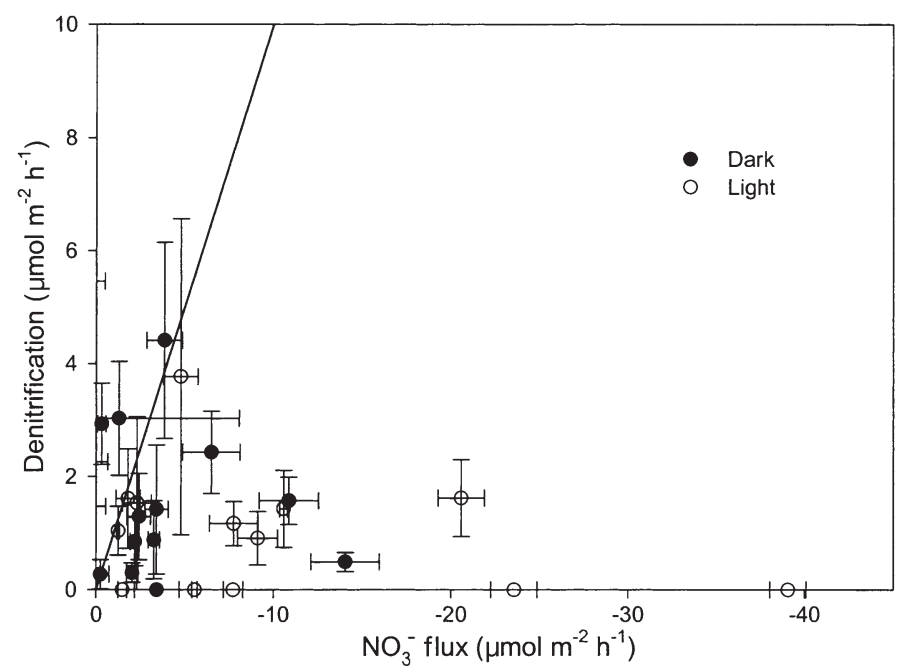

Fig 6. Denitrification versus $\mathrm{NO}_{3}{ }^{-}$flux measured in light and dark; line shows 1:1 relationship between denitrification and $\mathrm{NO}_{3}^{-}$flux

\section{$\mathbf{N}_{2}$ fixation}

The rates of $\mathrm{N}_{2}$ fixation measured in this study were comparable to those reported for other temperate intertidal sediments. In an intertidal cyanobacterial mat community, Paerl et al. (1996) reported acetylene reduction rates that, when converted to $\mathrm{N}_{2}$ fixation rates (using an acetylene-to- $\mathrm{N}_{2}$ ratio of 4 ), ranged from $<5$ to $200 \mu \mathrm{mol} N$ $\mathrm{m}^{-2} \mathrm{~h}^{-1}$. As in our study, they observed the highest rates at night during summer. In a Massachusetts salt marsh, $\mathrm{N}_{2}$ fixation rates by cyanobacteria ranged from essentially undetectable to $\sim 700 \mu \mathrm{mol} \mathrm{N} \mathrm{m}^{-2} \mathrm{~h}^{-1}$, with values generally falling in the range of 30 to $60 \mu \mathrm{mol} \mathrm{N} \mathrm{m} \mathrm{N}^{-2} \mathrm{~h}^{-1}$ (Carpenter et al. 1978). It was found that light and an availability of fixed nitrogen were the primary factors controlling $\mathrm{N}_{2}$ fixation in that system. The low winter rates of $\mathrm{N}_{2}$ fixation in our study, and the others cited above, are most probably a consequence of suppressed nitrogenase activity due to low light availability, low temperatures and higher concentrations of dissolved inorganic nitrogen within the water column.

The high rates of $\mathrm{N}_{2}$ fixation observed at Site $\mathrm{CF}$ were most probably due to cyanobacteria, including Oscillatoria spp., which were observed on the surface of the mudflat at this site. Pigment analysis also suggested these cyanobacteria made up a significant fraction of the MPB community at Site CF (Cook et al. 2004 b). There was also a significant variation in $\mathrm{N}_{2}$ fixation rates in response to light. Rates of light $\mathrm{N}_{2}$ fixation were significantly related to levels of chlorophyll a $(\mathrm{chl} a)$ in the sediment surface $(\mathrm{r}=0.51, \mathrm{p}=0.05)$, supporting the contention that cyanobacteria were responsible for $\mathrm{N}_{2}$ fixation. The significantly greater rates of $\mathrm{N}_{2}$ fixation seen in the dark at Site CF are consistent with previous studies of sediments colonised by non-heterocystous cyanobacteria (Stal 1995).

Consistent with the pattern of $\mathrm{N}_{2}$ fixation observed here was the seasonal pattern of $\delta^{15} \mathrm{~N}$ values observed at this site by Cook et al. (2004b). During summer and autumn the $\delta^{15} \mathrm{~N}$ of the sediment was relatively depleted, reflecting the contribution of ${ }^{15} \mathrm{~N}$-depleted organic matter, consistent with that expected from $\mathrm{N}_{2}$-fixing organisms (Capone et al. 1998, MacGregor et al. 2001). During winter, the $\delta^{15} \mathrm{~N}$ of the surface sediment became more enriched, concomitant with low $\mathrm{N}_{2}$ fixation rates and a greater reliance on $\mathrm{NO}_{3}{ }^{-}$assimilation from the water column by MPB (Fig. 4). It has been shown that the Huon estuary derives most of its nitrogen from the Southern Ocean in the form of nitrate (Butler et al. 2000) which has a $\delta^{15} \mathrm{~N}$ in excess of $6 \%$ (Lourey et al. 2003). As such, the observed increase in the $\delta^{15} \mathrm{~N}$ of the sediment surface during winter and spring is consistent with a greater reliance on fixed nitrogen $\left(\mathrm{NO}_{3}{ }^{-}\right)$which is relatively enriched in ${ }^{15} \mathrm{~N}$ compared to that derived directly from $\mathrm{N}_{2}$ fixation. 


\section{Nitrogen assimilation by microphytobenthos}

In this study, a comparison of the rates of $\mathrm{N}_{2}$ fixation and the calculated rate of total dissolved nitrogen uptake is complicated by the fact that the $\mathrm{N}_{2}$ fixation and nutrient/ $\mathrm{TCO}_{2}$ uptake measurements were made in different years. Interannual variability in rates of primary production and nitrogen availability may confound the interpretation of these results. The temporal variations in dissolved nitrogen in the Huon Estuary have been well characterised by the recently completed Huon Estuary study (Butler et al. 2000). The 3 yr study showed that the concentration of dissolved inorganic nitrogen (DIN) in the surface waters of the estuary followed a well-defined annual cycle, with maximum concentrations $(\sim 7 \mu \mathrm{M})$ observed between April and October. During the warmer months between October and April, DIN concentrations in the surface waters were always lower and generally $<1 \mu \mathrm{M}$. Based on these data, it seems reasonable to assume that the rates of nitrogen supply from the water column to the MPB are not likely to have differed significantly between 2001 and 2002. The rates of nitrogen supply from within the sediment were also assumed not to vary between 2001 and 2002. Chl a concentrations measured during the $2002 \mathrm{~N}_{2}$-fixation surveys were significantly greater than those measured during 2001 (data not shown). Given greater chl a concentrations and the significant positive relationship between chl $a$ and $\mathrm{N}_{2}$ fixation, it is highly likely that the measured rates of $\mathrm{N}_{2}$ fixation during 2002 would be greater than those in 2001. The rates of $\mathrm{N}_{2}$ fixation measured in 2002 could thus be considered a maximum estimate for 2001.

The estimates of daily $\mathrm{TCO}_{2}$ and nitrogen assimilation ratios in this study showed that even when the maximum rate of $\mathrm{N}_{2}$ fixation measured during 2002 at each site was used, the estimated ratio of C:N assimilated was around 20 in all seasons except winter. During nutrient limitation, the C:N-ratio of phytoplankton cells (and presumably MPB) may increase up to 20 (Van den Meersche et al. 2004); however, beyond this point, fixed carbon will be released as extracellular organic carbon (EOC). During nutrient limitation it has been shown that cultured MPB will continue to fix carbon, but then excrete this in the form of EOC (Stal 1995, Staats et al. 2000, Thornton 2002); this most probably occurs as a consequence of overflow metabolism (Stal 1995, Staats et al. 2000). During periods of low nutrient availability, the bulk of carbon assimilation may be directed to the synthesis of EOC instead of to cellular growth. MPB in particular, have been observed to have high rates of EOC production, with up to $73 \%$ of carbon fixed being converted into EOC compared to $23 \%$ for phytoplankton (Goto et al. 1999). The production of EOC may thus provide a sink for the excess carbon assimilated over nitrogen observed in the present study.
Acknowledgements. We thank C. Burke for critically reading an earlier version of this manuscript, and for assistance in setting up the oxygen micro-electrodes. B. O'Grady is thanked for critically reading the manuscript and financial assistance. J. Parslow read and made useful comments on an earlier version of this manuscript. We thank H. Roey and J. Middelburg for stimulating discussions. J. Middelburg, U. Witte and 2 anonymous referees, whose thoughtful comments substantially improved an earlier version of this manuscript, are thanked. Thanks to R. Watson, V. Latham and K. Berry for assistance with nutrient analysis. A. Bissett, H. Forehead, H. Cook, G. Wilson, K. Phillips and M. Shaw kindly assisted with field work. R. Jung helped with the initial design of sediment corers. Funding sources, including a Coasts and Clean Seas grant (CCS104/00) from the National Heritage Trust and an Australian Postgraduate Association (APA) scholarship for P.L.M.C. are also gratefully acknowledged.

\section{LITERATURE CITED}

Alongi DM, Boto KG, Robertson AI (1992) Nitrogen and phosphorus cycles. In: Robertson AI, Alongi DM (eds) Tropical mangrove ecosystems. American Geophysical Union, Washington, DC, p 251-292

Archer D, Devol A (1992) Benthic oxygen fluxes on the Washington shelf and slope-a comparison of in situ microelectrode and chamber flux measurements. Limnol Oceanogr 37:614-629

Asmus RM, Jensen MH, Jensen KM, Kristensen E, Asmus H, Wille A (1998) The role of water movement and spatial scaling for measurement of dissolved inorganic nitrogen fluxes in intertidal sediments. Estuar Coast Shelf Sci 46: 221-232

Berg P, Rysgaard S, Funch P, Sejr MK (2001) Effects of bioturbation on solutes and solids in marine sediments. Aquat Microb Ecol 26:81-94

Blackburn TH (1988) Benthic mineralization and bacterial production. In: Blackburn TH, Sorensen J (eds) Nitrogen cycling in coastal marine environments, Vol 33. John Wiley \& Sons, Chichester, p 175-190

Blackburn TH, Blackburn ND (1993) Rates of microbial processes in sediments. Phil Trans R Soc Lond 344:49-58

Blackburn TH, Hall POJ, Hulth S, Landén A (1996) Organic-N loss by efflux and burial associated with a low efflux of inorganic $\mathrm{N}$ and with nitrate assimilation in Arctic sediments (Svalbard, Norway). Mar Ecol Prog Ser 141:283-293

Broeker WS, Peng TH (1974) Gas exchange rates between air and sea. Tellus 26:21-35

Burdige DJ, Zheng S (1998) The biogeochemical cycling of dissolved organic nitrogen in estuarine sediments. Limnol Oceanogr 43:1796-1813

Butler ECV, Parslow JP, Volkman JK, Blackburn SI and 22 others (2000) Huon Estuary study-environmental research for integrated catchment management and aquaculture. Final report to the Fisheries Research and Development Corporation project number 96/284. Report No. FRDC proj no 96/284, CSIRO Division of Marine Research. Marine Laboratories, Hobart, Tasmania. Also available at www.marine.csiro.au/research/sme/huonest/report/index. html

Cabrita MT, Brotas V (2000) Seasonal variation in denitrification and dissolved nitrogen fluxes in intertidal sediments of the Tagus estuary, Portugal. Mar Ecol Prog Ser 202:51-65

Capone DG (1993) Determination of nitrogenase activity in aquatic samples using the acetylene reduction procedure. In: Kemp PF, Sherr BF, Sherr EB (eds) Handbook of meth- 
ods in aquatic microbial ecology. Lewis Publishers, Boca Raton, FL, p 621-631

Capone DG, Subramaniam A, Montoya JP, Voss M, Humborg C, Johansen AM, Siefert RL, Carpenter EJ (1998) An extensive bloom of the $\mathrm{N}_{2}$-fixing cyanobacterium Trichodesmium erythraeum in the central Arabian Sea. Mar Ecol Prog Ser 172:281-292

Carpenter EJ, Raalte V, Valiela I (1978) Nitrogen fixation by algae in a Massachusetts salt marsh. Limnol Oceanogr 23: 318-327

Charpy-Roubaud C, Charpy L, Larkum AWD (2001) Atmospheric dinitrogen fixation by benthic communities of Tikehau Lagoon (Tuamotu Archipelago, French Polynesia) and its contribution to benthic primary production. Mar Biol 139:991-997

Cook PLM, Butler ECV, Eyre BD (2004a) Carbon and nitrogen cycling on intertidal mudflats of a temperate Australian estuary. I. Benthic metabolism. Mar Ecol Prog Ser 280: 25-38

Cook PLM, Revill AT, Clementson LA, Volkman JK (2004b) Carbon and nitrogen cycling on intertidal mudflats of a temperate Australian estuary. III. Sources of organic matter. Mar Ecol Prog Ser 280:55-72

Coull BC (1999) Role of meiofauna in estuarine soft-bottom habitats. Aust J Ecol 24:327-343

Dalsgaard T, Nielsen LP, Brotas V, Viaroli P and 10 others (2000) Protocol handbook for NICE - nitrogen cycling in estuaries: a project under the EU research programme: Marine Science and Technology (MAST III), National Environmental Research Institute, Silkeborg

Decho AW (1990) Microbial exopolymer secretions in ocean environments - their role(s) in food webs and marine processes. Oceanogr Mar Biol Annu Rev 28:73-153

Dong LF, Thornton DCO, Nedwell DB, Underwood GJC (2000) Denitrification in sediments of the River Colne estuary, England. Mar Ecol Prog Ser 203:109-122

Enoksson V (1993) Nutrient recycling by coastal sediments-effects of added algal material. Mar Ecol Prog Ser 92:245-254

Epstein SS (1997) Microbial food webs in marine sediments. 1. Trophic interactions and grazing rates in two tidal flat communities. Microb Ecol 34:188-198

Eyre BD, Ferguson AJP (2002) Comparison of carbon production and decomposition, benthic nutrient fluxes and denitrification in seagrass, phytoplankton, benthic microalgaeand macroalgae-dominated warm-temperate Australian lagoons. Mar Ecol Prog Ser 229:43-59

Falcão M, Vale C (1998) Sediment-water exchanges of ammonium and phosphate in intertidal and subtidal areas of a mesotidal coastal lagoon (Ria Formosa). Hydrobiologia 374:193-201

Ferguson AJP (2002) Nutrient cycling in shallow sub-tropical estuaries, New South Wales, Australia. PhD thesis, Southern Cross University, Lismore

Goto N, Kawamura T, Mitamura O, Terai H (1999) Importance of extracellular organic carbon production in the total primary production by tidal-flat diatoms in comparison to phytoplankton. Mar Ecol Prog Ser 190:289-295

Goto N, Mitamura O, Terai H (2001) Biodegradation of photosynthetically produced extracellular organic carbon from intertidal benthic algae. J Exp Mar Biol Ecol 257:73-86

Granum E, Kirkvold S, Mykelstad SM (2002) Cellular and extracellular production of carbohydrates and amino acids by the marine diatom Skeletonema costatum: diel variations and effects of N depletion. Mar Ecol Prog Ser 242:83-94

Grasshoff K (1976) Methods of seawater analysis. Verlag Chemie, New York

Green MA, Gulnick JD, Dowse N, Chapman P (2004) Spatio- temporal patterns of carbon remineralization and bioirrigation in sediment of Casco Bay Estuary, Gulf of Maine. Limnol Oceanogr 49:396-407

Hansen LS, Blackburn TH (1992) Effect of algal bloom deposition on sediment respiration and fluxes. Mar Biol 112: $147-152$

Harris GP (2001) Biogeochemistry of nitrogen and phosphorus in Australian catchments, rivers and estuaries: effects of land use and flow regulation and comparisons with global patterns. Mar Freshw Res 52:139-149

Henriksen K, Kemp WM (1988) Nitrification in estuarine and coastal marine sediments. In: Blackburn TH, Sorensen J (eds) Nitrogen cycling in coastal marine environments, Vol 33. John Wiley \& Sons, Chichester, p 207-249

Iversen N, Jørgensen BB (1993) Diffusion coefficients of sulfate and methane in marine sediments-influence of porosity. Geochim Cosmochim Acta 57:571-578

Jensen KM, Jensen MH, Kristensen E (1996) Nitrification and denitrification in Wadden Sea sediments (Königshafen, Island of Sylt, Germany) as measured by nitrogen isotope pairing and isotope dilution. Aquat Microb Ecol 11:181-191

Jickells TD, Rae JE (eds) (1997) Biogeochemistry of intertidal sediments, Vol 9. Cambridge University Press, Cambridge

Kemp PF (1990) The Fate of benthic bacterial production. Rev Aquat Sci 2:109-124

Kristensen E (1993) Seasonal variations in benthic community metabolism and nitrogen dynamics in a shallow, organicpoor Danish lagoon. Estuar Coast Shelf Sci 36:565-586

Landén A, Hall POJ (2000) Benthic fluxes and porewater distributions of dissolved free amino acids in the open Skagerrak. Mar Chem 71:53-68

Li Y, Gregory S (1974) Diffusion of ions in seawater and in deepsea sediments. Geochim Cosmochim Acta 38:703-714

Lomstein BA, Jensen AGU, Hansen JW, Andreasen JB, Hansen LS, Berntsen J, Kunzendorf H (1998) Budgets of sediment nitrogen and carbon cycling in the shallow water of Knebel Vig, Denmark. Aquat Microb Ecol 14:69-80

Lourey MJ, Trull TW, Sigman DM (2003) Sensitivity of $\delta 15 N$ of nitrate, surface suspended and deep sinking particulate nitrogen to seasonal nitrate depletion in the Southern Ocean. Global Biogeochem Cycles 17:A1081

MacGregor BJ, Van Mooy B, Baker BJ, Mellon M and 5 others (2001) Microbiological, molecular biological and stable isotopic evidence for nitrogen fixation in the open waters of Lake Michigan. Environ Microbiol 3:205-219

Magalhães CM, Bordalo AA, Wiebe WJ (2002) Temporal and spatial patterns of intertidal sediment-water nutrient and oxygen fluxes in the Duoro River estuary, Portugal. Mar Ecol Prog Ser 233:55-71

Malcolm SJ, Sivyer DB (1997) Nutrient recycling in intertidal sediments. In: Jickells TD, Rae JE (eds) Biogeochemistry of intertidal sediments, Vol 9. Cambridge University Press, Cambridge, p 85-98

Matisoff G, Wang XS (1998) Solute transport in sediments by freshwater infaunal bioirrigators. Limnol Oceanogr 43: 1487-1499

Meile C, Van Cappellen P (2003) Global estimates of enhanced solute transport in marine sediments. Limnol Oceanogr 48: 777-786

Meyer-Reil LA, Faubel A (1980) Uptake of organic matter by meiofauna organisms and interrelationships with bacteria. Mar Ecol Prog Ser 3:251-256

Meysman FJR, Boudreau BP, Middelburg JJ (2003) Relations between local, nonlocal, discrete and continuous models of bioturbation. J Mar Res 61:391-410

Middelburg JJ, Klaver G, Nieuwenhuize J, Markusse RM, Vlug T, Vandernat FJWA (1995a) Nitrous oxide emissions 
from estuarine intertidal sediments. Hydrobiologia 311: 43-55

Middelburg JJ, Klaver G, Nieuwenhuize J, Vlug T (1995b) Carbon and nitrogen cycling in intertidal sediments near Doel, Scheldt Estuary. Hydrobiologia 311:57-69

Montoya JP, Voss M, Kahler P, Capone DG (1996) A simple, high-precision, high-sensitivity tracer assay for $\mathrm{N}_{2}$ fixation. Appl Environ Microbiol 62:986-993

Mortimer RJG, Davey JT, Krom MD, Watson PG, Frickers PE, Clifton RJ (1999) The effect of macrofauna on porewater profiles and nutrient fluxes in the intertidal zone of the Humber Estuary. Estuar Coast Shelf Sci 48:683-699

Nagao F, Miyazaki T (2002) Release of dissolved organic nitrogen from Scenedesmus quadricauda (Chlorophyta) and Microcystis novacekii (Cyanobacteria). Aquat Microb Ecol 27:275-284

Nedwell DB, Jickells TD, Trimmer M, Sanders R (1999) Nutrients in estuaries. In: Nedwell DB, Raffaelli DG (eds) Advances in ecological research-estuaries. Academic Press, San Diego, p 43-92

Nielsen LP (1992) Denitrification in sediment determined from nitrogen isotope pairing. FEMS Microbiol Ecol 86:357-362

Ogilvie B, Nedwell DB, Harrison RM, Robinson A, Sage A (1997) High nitrate, muddy estuaries as nitrogen sinksthe nitrogen budget of the River Colne Estuary (United Kingdom). Mar Ecol Prog Ser 150:217-228

Ottosen LDM, Risgaard-Petersen N, Nielsen LP, Dalsgaard T (2001) Denitrification in exposed intertidal mud-flats, measured with a new ${ }^{15} \mathrm{~N}$-ammonium spray technique. Mar Ecol Prog Ser 209:35-42

Paerl HW, Fitzpatrick M, Bebout BM (1996) Seasonal nitrogen fixation dynamics in a marine microbial mat: potential roles of cyanobacteria and microheterotrophs. Limnol Oceanogr 41:419-427

Pedersen AGU, Bernsten J, Lomstein BA (1999) The effect of eelgrass decomposition on sediment carbon and nitrogen cycling: a controlled laboratory experiment. Limnol Oceanogr 44:1978-1992

Petty RL, Michel WC, Snow JP, Johnson KS (1982) Determination of total primary amines in sea water and plant nectar with flow injection sample processing and fluorescence detection. Analyt Chim Acta 142:299-304

Pinckney J, Paerl HW, Fitzpatrick M (1995) Impacts of seasonality and nutrients on microbial mat community structure and function. Mar Ecol Prog Ser 123:207-216

Price NM, Harrison PJ (1987) Comparison of methods for the analysis of dissolved urea in seawater. Mar Biol 94:307-317

Risgaard-Petersen N (2003) Coupled nitrification-denitrification in autotrophic and heterotrophic sediments: on the influence of benthic microalgae. Limnol Oceanogr 48:93-105

Risgaard-Petersen N, Rysgaard S, Nielsen LP, Revsbech NP (1994) Diurnal variation of denitrification and nitrification in sediments colonized by benthic microphytes. Limnol Oceanogr 39:573-579

Rocha C (1998) Rhythmic ammonium regeneration and flushing in intertidal sediments of the Sado Estuary. Limnol Oceanogr 43:823-831

Rocha C, Cabeçadas G, Brogueira MJ (1995) On the importance of sediment water exchange processes of ammonia to primary production in shallow areas of the Sado Estuary (Portugal). Neth J Aquat Ecol 29:265-273

Rysgaard S, Risgaard-Petersen N, Nielsen LP, Revsbech NP (1993) Nitrification and denitrification in lake and estuarine sediments measured by the ${ }^{15} \mathrm{~N}$ dilution technique and isotope pairing. Appl Environ Microbiol 59:2093-2098

Rysgaard S, Christensen PB, Nielsen LP (1995) Seasonal variation in nitrification and denitrification in estuarine sedi- ment colonized by benthic microalgae and bioturbating infauna. Mar Ecol Prog Ser 126:111-121

Rysgaard S, Christensen PB, Sorensen MV, Funch P, Berg P (2000) Marine meiofauna, carbon and nitrogen mineralization in sandy and soft sediments of Disko Bay, West Greenland. Aquat Microb Ecol 21:59-71

Soetaert K, Herman PMJ, Middelburg JJ (1996) A model of early diagenetic processes from the shelf to abyssal depths. Geochim Cosmochim Acta 60:1019-1040

Staats N, Stal LJ, Mur LR (2000) Exopolysaccharide production by the epipelic diatom Cylindrotheca closterium: effects of nutrient conditions. J Exp Mar Biol Ecol 249:13-27

Stal LJ (1995) Physiological ecology of cyanobacteria in microbial mats and other communities. New Phytol 131:1-32

Strauss EA, Lamberti GA (2000) Regulation of nitrification in aquatic sediments by organic carbon. Limnol Oceanogr 45:1854-1859

Sundbäck K, Miles A (2000) Balance between denitrification and microalgal incorporation of nitrogen in microtidal sediments, NE Kattegat. Aquat Microb Ecol 22:291-300

Sundbäck K, Enoksson V, Granéli W, Pettersson K (1991) Influence of sublittoral microphytobenthos on the oxygen and nutrient flux between sediment and water: a laboratory continuous flow study. Mar Ecol Prog Ser 74:263-279

Sundbäck K, Miles A, Göransson E (2000) Nitrogen fluxes, denitrification and the role of microphytobenthos in microtidal shallow-water sediments: an annual study. Mar Ecol Prog Ser 200:59-76

Thornton DCO (2002) Diatom aggregation in the sea: mechanisms and ecological implications. Eur J Phycol 37:149-161

Thornton DCO, Underwood GJC, Nedwell DB (1999) Effect of illumination and emersion period on the exchange of ammonium across the estuarine sediment-water interface. Mar Ecol Prog Ser 184:11-20

Trimmer M, Nedwell DB, Sivyer DB, Malcolm SJ (1998) Nitrogen fluxes through the lower estuary of the River Great Ouse, England-the role of the bottom sediments. Mar Ecol Prog Ser 163:109-124

Trimmer M, Nedwell DB, Sivyer DB, Malcolm SJ (2000) Seasonal organic mineralisation and denitrification in intertidal sediments and their relationship to the abundance of Enteromorpha sp. and Ulva sp. Mar Ecol Prog Ser 203:67-80

Tuominen L, Makela K, Lehtonen KK, Haahti H, Hietanen S, Kuparinen J (1999) Nutrient fluxes, porewater profiles and denitrification in sediment influenced by algal sedimentation and bioturbation by Monoporeia affinis. Estuar Coast Shelf Sci 49:83-97

Tyler AC, McGlathery KJ, Anderson IC (2001) Macroalgae mediation of dissolved organic nitrogen fluxes in a temperate coastal lagoon. Estuar Coast Shelf Sci 53:155-168

Underwood GJC, Kromkamp J (1999) Primary production by phytoplankton and microphytobenthos in estuaries. In: Nedwell DB, Raffaelli DG (eds) Advances in ecological research - estuaries, Vol 29. Academic Press, San Diego, p 93-153

Underwood GJC, Paterson DM, Parkes RJ (1995) The measurement of microbial carbohydrate exopolymers from intertidal sediments. Limnol Oceanogr 40:1243-1253

Valderrama JC (1981) The simultaneous analysis of TP and TN in natural waters. Mar Chem 10:109-122

Van den Meersche K, Middelburg JJ, Soetaert K, Rijswijk P, Boschker HTS, Heip CHR (2004) Carbon-nitrogen coupling and algal-bacterial interactions during an experimental bloom: Modelling a ${ }^{13} \mathrm{C}$ tracer experiment. Limnol Oceanogr 49:1862-1878

van Duyl FC, van Raaphorst W, Kop AJ (1993) Benthic bacterial production and nutrient sediment-water exchange in sandy North Sea sediments. Mar Ecol Prog Ser 100:85-95 